\title{
Evangelielæsningens placering og funktion i dansk højmesseordning
}

\author{
Provst emeritus, cand.theol. \\ Holger Villadsen
}

\begin{abstract}
This article examines the place of the Gospel reading and the Creed in Danish liturgy. In the first centuries after the Reformation, the Gospel was sung from the altar followed by the Creed, normally a Danish hymn. The Gospel was read once more from the pulpit before the sermon. In the 19th century, the Gospel was often only read from the pulpit in connection with the sermon and the Creed gradually disappeared. At the end of the 19th century, a new lectionary was introduced with two years and two different Gospel readings: the first from the altar, the second from the pulpit as the text for the sermon. In the middle of the 20th century, the Creed was reinstated after the Gospel from the altar, but now as the Apostles' Creed. In 1992, the Danish Church got a new Service Book with three biblical readings: Old Testament, Epistle and Gospel. Here the Gospel is normally read from the pulpit and the Apostles' Creed read or sung from the altar after the Epistle.
\end{abstract}

Key words: Danish liturgy - order of worship - Gospel reading - the Creed - altar - pulpit - service book - hymn book - lectionary - half Mass

\section{Indledning}

Emnet for denne artikel er evangelielæsningens placering og funktion i dansk højmesseordning siden reformationen. Det er et vigtigt punkt i højmesseordningens grundlæggende struktur, som der kun i begrænset omfang har været fokus på i litteraturen om dansk liturgi.

Der har i perioden været to placeringsmuligheder. Den første er fra alteret som den sidste og vigtigste af de bibelske læsninger. Det er en placering i forlængelse af den oldkirkelige og middelalderlige liturgitradition, hvor evangelielæsningen indgår som en del af højmessens liturgiske forløb.

Den anden placering er fra prædikestolen som prædiketekst i tæt sammenhæng med prædikenen. Det er en placering, der blev indført i forbindelse med reformationen og forudsatte, at der var en prædikestol, hvad der ofte ikke var tilfældet i den første tid efter reformationen. Der er kun få eksempler på senmiddelalderlige prædikestole i 
Danmark, og de fleste kirker fik først prædikestole i sidste halvdel af 1500-tallet og første halvdel af 1600-tallet.

De to placeringsmuligheder findes i forskellige kombinationer, men det meste af tiden har det været et både-og, hvor den samme evangelietekst blev læst to gange. Den blev både sunget fra alteret som liturgisk læsning og læst fra prædikestolen som prædiketekst.

Indirekte vedrører spørgsmålet om evangelielæsningens placering også trosbekendelsens placering. For det meste har det været sådan, at trosbekendelsen fulgte efter den liturgiske evangelielæsning fra alteret. Sådan var det i de første århundreder efter reformationen i forlængelse af den middelalderlige tradition, og sådan var det også i en stor del af 1900-tallet.

I de perioder, hvor der ikke har været en fast evangelielæsning fra alteret, har trosbekendelsen skullet finde en anden plads. I 1800-tallet endte det med, at trosbekendelsen i praksis næsten ikke blev brugt i gudstjenesten. Og i højmesseordningen fra 1992 er trosbekendelsen som udgangspunkt placeret fra alteret efter den anden bibelske læsning, epistlen.

Emnet for denne artikel er ikke tidligere blevet behandlet selvstændigt og udførligt i artikler eller monografier. Højmesseordningen i dansk liturgi er naturligvis blevet behandlet $\mathrm{i}$ kirkehistoriske håndbøger, i liturgihistoriske fremstilinger og i monografier om fx. liturgisk musik, men der har ikke i disse sammenhænge været mulighed for at gå så meget i dybden med evangelielæsningens placering, som jeg har forsøgt i denne artikel, hvor jeg har koncentreret mig om en selvstændig læsning af de almindeligt anvendte kilder, samt forsøgt at inddrage supplerende kilder, som ikke tidligere har været brugt i denne sammenhæng.

\section{Den første periode efter reformationen i Danmark}

De grundlæggende bestemmelser om højmesseordningen i de første 150 år i Danmark efter reformationens indførelse findes i den danske Kirkeordinans fra $1539 .{ }^{1}$ Hvis man i Kirkeordinansen holder sig til højmesseordningen alene, ser det tilsyneladende ud til, at der kun

1. Første danske tryk: Den rette Ordinants som nu sist paa Herre dagen y Ottense bleff offuer seet oc besegelet ... Kiøbmanhaffn: Hans Wyngaardt 1542. Jeg bruger en moderne udgave: Martin Schwarz Lausten. Kirkeordinansen 1537/1539. Det danske Udkast til Kirkeordinansen (1537). Ordinatio Ecclesiastica Regnorum Danie et Norwegic et Ducatum Sleswicensis Holtsatia etc. (1537). Den danske Kirkeordinans (1539). Tekstudgave med indledning og noter. København: Akademisk Forlag 1989. 
har været én evangelielæsning, nemlig evangelielæsningen fra alteret efterfulgt af trosbekendelsen i form af trossalmen samt prædikenen.

Ifølge Kirkeordinansens anvisninger skal præsten fra alteret læse epistlen på dansk vendt mod folket. Efter epistellæsningen synges et halleluja og en dansk salme. Og derefter læser præsten evangeliet fra alteret:

$\mathrm{Nu}$ wender hand seg til folcked igien, oc læss Euangelium paa danske, med denne begyndelse, disse efterfølgende ord etc. Der nest vender hand seg atter til Alterid oc begynder, Credo in unum Deum etc. Der effter siungis paa Danske Wy troe allesammen paa een Gud etc. Her effter skal nu den wonlige predicken skee, oc naar hun er vde, ere der da de som wille berettis, saa berede seg dennom brød oc win, ... (Lausten 1989, 170-171).

I højmesseordningens liturgiske forløb er evangelielæsningen placeret efter epistellæsningen. Det er en generel tendens i alle klassiske perikopeordninger, at de bibelske læsninger læses i en stigende rangrækkefølge, og at evangelielæsningen er placeret som den sidste og vigtigste læsning.

Umiddelbart efter evangelielæsningen følger trosbekendelsen i form af en trossalme. Den intoneres af præsten, og synges derefter på dansk.

Stedet for evangelielæsningen er alteret. Det fremgår klart af konteksten i Kirkeordinansen. Præsten går for alteret under Confiteor og bliver der under den første del af gudstjenesten. Præstens placering ved alteret under evangelielæsningen fremgår indirekte af bemærkningen om, at han efter læsningen igen vender sig mod alteret under trosbekendelsen.

Det er et generelt træk i de klassiske liturgier, at evangelielæsningen fremhæves i forhold til den eller de forudgående læsninger. ${ }^{2}$ En sådan fremhævelse er der så godt som ikke spor af i Kirkeordinansen. En antydning af en fremhævelse findes måske $i$, at der er en anvisning om, hvordan evangelielæsningen skal indledes. Og en anden antydning findes måske i det træk, at evangelielæsningen efterfølges af trosbekendelsen.

Præsten har været iført messeklæder under evangelielæsningen, men det er ikke en speciel fremhævelse af evangelielæsningen, for det har han været under det meste af gudstjenesten, eller måske under

2. Eksempler på evangelielæsningens særlige status i forhold til de andre bibelske læsninger kan findes fx hos Josef Andreas Jungmann. Missarum sollemnia. Eine genetische Erklärung der römischen Messe. Fünfte, verbesserte Auflage. Freiburg: Herder 1962, bind I, 565-583. 
hele gudstjenesten. I indledningen til afsnittet om højmessen står der, at præsten er iført de sædvanlige messeklæder (Lausten 1989, 166). Og der står ikke noget om, at han aflægger messeklæderne før til allersidst efter velsignelsen og den sidste salme (Lausten 1989, 173).

\section{Pradiken indledt med evangelielasning}

I det meste af den eksisterende sekundærlitteratur om dansk liturgihistorie regner man med, at der i den danske højmesseordning i denne periode kun har været én evangelielæsning. ${ }^{3}$ Men hvis man inddrager andre kilder, ser det ud til, at evangelielæsningen fra alteret også i denne første fase af dansk liturgi er blevet gentaget i forbindelse med prædikenen, ligesom det er tilfældet i den efterfølgende ordning fra Kirkeritualet $1685 .{ }^{4}$

Umiddelbart efter højmesseordningen er der i Kirkeordinansen et kapitel om prædikenen. Efter en kort generel indledning står der:

Først skal hand da, som prædickendis vorder, formane folcket til at paakalde Guds Hielp, Dernest skal hand fortellie Texten som skal forklares, oc siden vdlægge hende, Oc ey skal hand forlenge sin prædicken offuer een tyme (Lausten 1989, 174).

Der ser ikke ud til at være tale om en egentlig gentagelse af oplæsningen af evangeliet, kun om en genfortælling eller en parafrase af teksten som indledning til prædikenen.

Uanset hvad meningen har været med ordlyden i Kirkeordinansen, præciserer biskopperne på et bispemøde i 1540 bestemmelsen om indledningen til prædikenen sådan, at evangelieteksten skal læses. Det er ikke nok at genfortælle den. Beslutningen på bispemødet lød således: "De concione: ... Textus euangelii recitetur simpliciter primum sine omni adiectione glosematum, post explicetur etc."

Denne beslutning om en gentagelse af evangelielæsningen uden tilføjelser og bemærkninger svarer ret nøje til de senere bestemmelser i

3. Se fx Bent Flemming Nielsen. Højmessen: Historie og teologi. København: Eksistensen 2020, 87-88; Søren Sørensen. Kirkens Liturgi. 2. rev. udgave. København: Wilhelm Hansens Musikforlag 1969, 64; K.E. Skydsgaard. "Kirkens Gudstjeneste". I Haandbog i Kristendomskundskab, red. Aage Bentzen m.fl. København: Munksgaard 1943, bind 6, 40.

4. Jf. oversigten hos Christian Thodberg. Den forsømte Gudstjeneste. København: Gad 1965, 70-71. Her forudsættes det også, at der i denne periode er en evangelielæsning fra prædikestolen forud for prædikenen.

5. Holger Fr. Rørdam. Danske Kirkelove ... fra Reformationen indtil Christian V's Danske Lov, 1536-1683, bind I, 154. Kjøbenhavn: Selskabet for Danmarks Kirkehistorie 1883. 
Kirkeritualet 1685, og jeg formoder, at Kirkeritualets bestemmelser på dette punkt kun er en forlængelse af regler og praksis i de første 150 år efter reformationen. ${ }^{6}$

I samme retning peger Kirkeordinansens anvisninger om, at præster på landet indtil videre må oplæse prædikenen fra en dansk postille (Lausten 1989, 176). Postillerne var nemlig ikke kun prædikensamlinger, men også perikopebøger med højmessens bibelske læsninger i dansk oversættelse. Det gælder fx Hans Tausens postille fra 1539. ${ }^{7}$ Bibelteksterne er i Hans Tausens postille trykt med større typer end prædikenen og fremhæves på den måde som et vigtigt element i postillen. Så hvis præsten læste prædikenen af en postille, ville han naturligt indlede med at læse evangelieperikopen.

\section{Vormordsens messehåndbog med højmesseordning}

Et samtidigt eksempel på en højmesseordning, der har to evangelielæsninger, først en liturgisk læsning fra alteret og dernæst en homiletisk gentagelse af evangeliet, findes i Vormordsens messehåndbog fra $1539 .{ }^{8}$ Frans Vormordsen var den første lutherske biskop i det tidligere ærkebispesæde i Lund og deltog i forhandlingerne forud for Kirkeordinansen. Han var i 1537 blevet indsat som superintendent sammen de andre nye lutherske superintendenter.

Vormordsens messehåndbog er en bog af en anden type end den latinske kirkeordinans, som er en lovbog med de overordnede regler for den danske kirkes virksomhed, herunder også en kort beskrivelse af hovedlinjerne i højmessen. Men Kirkeordinansen indeholder ikke de relevante tekster til højmessen, hverken de faste tekster eller de kirkeårsvariable. $\mathrm{Og}$ den latinske version fra 1537 var desuden ikke anvendelig i praksis, når højmessen efter de nye regler i stort omfang skulle holdes på dansk.

Vormordsen har derfor tilsyneladende ment, at der var brug for en praktisk håndbog på dansk med alle de relevante tekster på dansk og

6. Jf. Svend Borregaard. Danmarks og Norges Kirkeritual af 1685. København: Gad $1953,112$.

7. Hans Tausens postille er trykt i 1539 og består af tre dele: 1) Winterdelen aff Postillen, 2) Sommerdelen af Postillen samt 3) Wor Herres Jesu Christi Hellige Passies oc pinsels hystori. Moderne faksimileudgave: Bjørn Kornerup. Hans Tausens Postil. Med Indledning og Noter. Det danske Sprog- og Litteraturselskab, bind I-II. København: Munksgaard 1934.

8. [Frans Vormordsen:] Een gantske nyttelig oc alle sogneprester oc predicanter nødtørtelig Handbog Om den rette Euangeliske Messe ... Malmø: Oluf Ulriksen 1539. Moderne faksimileudgave i S.H. Poulsen. Danske messeboger fra reformationstiden. Udgivet i facsimile af Universitets-Jubilæets danske Samfund med en liturgihistorisk redegørelse. København: J.H. Schultz 1959. 
med de nødvendige noder. Han overlod arbejdet til Claus Mortensen, der var sognepræst i Malmø. Vormordsens forord er underskrevet i efteråret 1538, og bogen er derfor udarbejdet efter den latinske kirkeordinans fra 1537 og før den officielle danske version af kirkeordinansen, der blev godkendt i 1539 og trykt i 1542.

Messehåndbogen forsøger angiveligt at være $\mathrm{i}$ overensstemmelse med den latinske ordinans. Det fremgår af titelbladet, af flere henvisninger til ordinansen undervejs i teksten samt af et ordret citat på latin fra ordinansen om, hvordan der skal holdes messe, når der ikke er nogen, der skal til alters.'

Bugenhagen lod efterfølgende til at mene, at håndbogen på nogle punkter afveg fra Kirkeordinansen, især ved at bringe nadverpræfationer på dansk med latinske (gregorianske) noder. Og derfor kom der i den danske kirkeordinans fra 1539 nogle nye skærpede censurbestemmelser i forhold til den latinske kirkeordinans fra 1537 (Lausten 1989, 231-232). Men efter min vurdering er denne efterfølgende indirekte kritik og censur ikke relevant for de uddybende bestemmelser om evangelielæsningerne i Vormordsens messehåndbog. Den ser på dette punkt ud til at være en bedre og udførligere kilde til datidens praksis end Kirkeordinansen.

Evangelielæsningen fra alteret følger efter epistel, halleluja og salmesang. Og efter evangelielæsningen synges trosbekendelsen. Trosbekendelsen synges under alle omstændigheder som en dansk salme, men er der en latinskole knyttet til kirken, synges først Nikænum på latin. Om evangelielæsningen fra alteret står der:

Her effter vender presten sig til folked och less Euangelium siendis: Herren vere med eder. Folked suarer Oc medt din aandt. Presten siger: Desse effterfølgende euangelii ord bescriffuer oss S Mat. Folked suarer Gud vere loff for sit gladelige bodscaff. Saa leser hand da det hellige euangelium med seduanlige noder, som falder om samme dag oc findis i det ny testamente (Vormordsen 1539, blad C iiii).

I håndbogen er der anført noder til den indledende hilsen og til dialogen forud for selve evangelielæsningen. I store træk svarer tekst og noder til det, som man senere finder i Thomissøns salmebog fra 1569, så der er en vis sandsynlighed for, at det er håndbogens lidt mere udførlige indledning til evangelielæsningen, der bedst afspejler praksis i de første årtier efter Kirkeordinansen.

9. Vormordsen 1539, blad Giiv , er et citat fra den latinske kirkeordinans; jf. Lausten 1989, 104. 
Både epistlen og evangeliet læses ifølge håndbogen 1539 med de sædvanlige noder. De er altså blevet sunget eller messet. Og det er formentlig også den praksis, som ordinansen forudsætter, selv om der i den latinske version fra 1537 kun står, at evangeliet læses (Lausten 1989, 103), og tilsvarende i den danske version fra 1539 (Lausten 1989, 170).

Det fremgår af konteksten i Vormordsens håndbog, at præsten læser evangeliet fra alteret iført messeklæder. Men når præsten efter trosbekendelsen og salmen "Nu bede vi den Helligånd" går i prædikestolen, er det uden messehagel.
Oc naar Credo er ude med dene loffsang Nu bede vi den helligaand, som idelige for predicken siunges skal Saa gaar presten uden hagelsen i predickestolen, formanendis folcked at paakalle gudz naadis hielp oc den helligaandz delactighed vid Jesum cristum faldendis ydmygelige paa deris kne. Siden leeser hand klarlige den hellige euangelii text. Oc naar hun eer ude Begynder hand at forklare hende fra første oc til det siste ... (Vormordsen 1539, blad D iii').

Messehåndbogen beskriver klart to evangelielæsninger i højmessen, men de liturgiske omstændigheder omkring de to evangelielæsninger er tydeligt forskellige. Første gang fra alteret er det med messehagel, anden gang fra prædikestolen er det uden. Fra alteret messer præsten, mens han fra prædikestolen sandsynligvis kun læser. Fra alteret indleder præsten med hilsen og dialog med menighedssvaret "Gud vere loff for sit gladelige bodscaff", mens præsten fra prædikestolen indleder oplæsningen direkte efter at have opfordret menigheden til falde på knæ og bede en bøn.

Lidt forenklet kan det måske formuleres således, at den første evangelielæsning fra alteret er en liturgisk læsning og den anden en homiletisk læsning. Hvor den første læsning er et selvstændigt led i højmessens liturgiske forløb, betragtes den anden læsning fra prædikestolen som en del af prædikenen.

Messehåndbogen 1539 har på nogle punkter en selvstændig tolkning af Kirkeordinansen, som ikke får tilslutning i eftertiden, men hvad angår evangelielæsningen fra prædikestolen ser det ud til, at det bliver denne linje, der bliver den dominerende i de næste to århundreder. Og det er den ordning, som de danske superintendenter aftaler på mødet i København 1540. 


\section{Andre kilder fra 1500-tallet}

Peder Palladius' alterbog fra 1556 er en anden vigtig kilde til dansk liturgi. ${ }^{10}$ Den form og det indhold han giver alterbogen, kommer til at bestemme en linje i dansk liturgi helt frem til 1901, og også længere frem. Alterbogen indeholder kirkeårets tekster: indledningskollekterne, epistlerne og evangelierne. Derudover findes nadverritualet, brudevielsesritualet og dåbsritualet. Det meste af det præsten skulle bruge jævnligt, var samlet i en liturgisk brugsbog. Men der var ikke nogen samlet højmesseordning.

Efter Vormordsen var der ikke nogen, der vovede eller fik lov til at trykke en liturgisk håndbog med en samlet højmesseordning før midt i 1900-tallet. Man vil derfor lede forgæves i alterbøgerne eller andre liturgiske bøger efter nogenlunde komplette anvisninger om højmessens forløb.

Man kan dog i Palladius' forord finde en indirekte omtale af den dobbelte evangelielæsning. Palladius argumenterer for alterbogens praktiske anvendelighed i gudstjenesten i stedet for en bibel (Jakobsen 1918, 43). Den nye helbibel, Christian III's bibel fra 1550, var for stor og tung at bruge i kirken, når præsten skal vende sig om fra alteret mod almuen og læse af Bibelen. Og den var også for uhåndterlig at tage med op på prædikestolen. Bibelen skulle formentlig tages med op på prædikestolen, fordi evangeliet skulle læses endnu en gang i forbindelse med prædikenen. Derfor har Palladius fået sine medbrødres samtykke til at lade trykke en mindre og mere praktisk bog, som dog samtidigt havde en tilpas stor typografi. Og den skulle altså bruges både fra alteret og fra prædikestolen.

I Hans Thomissøns salmebog fra 1569 er der til sidst i bogen en oversigt over højmessens gang. ${ }^{11}$ Der er dog ikke tale om en egentlig højmesseordning med alle de relevante faste tekster til præsten, degnen og menigheden. Det er kun et register med højmessens hovedpunkter og henvisninger til de relevante salmer i salmebogen. Desuden er der i registret tekst og noder til de gudstjenesteled, hvor "Degnen oc Folckit" skal svare eller fortsætte efter præstens intonation.

Beskrivelsen af evangelielæsningen fra alteret svarer i store træk til beskrivelsen i Vormordsens messehåndbog:

10. Petrus Palladius. Søndagers Oc helige dagers Episteler oc Euangelia met Collecter oc andet at bruge vdi Christi Naduere effter Ordinantzens lydelse. Weydeborgk: Hans Walter 1556. Moderne udgave: Lis Jakobsen. Peder Palladius, Den aldste danske Alterbog, 1556, udgivet efter originalen. København: Gyldendal 1918.

11. Hans Thomissøn. Den danske Psalmebog met mange Christelige Psalmer. Kiøbenhaffn: Laurentz Benedicht 1569. Moderne faksimileudgave med samme titelblad som originalen. København: Levin \& Munksgaard 1933. 
Der effter vender Presten sig til Folckit, oc læss Euangelium aff Alterbogen, saaledis: Herren være met eder. Degnen oc Folckit suarer: Oc met din Aand. Presten siger fremdelis: Disse effterfølgendis Ord bescriffuer oss den hellig Lucas Euangelista. Degnen oc Folckit suarer: Gud være loffuit for sit gladeligt budskab (Thomissøn 1569, blad Aaa iiiiv).

Derefter fortsætter præsten med at synge evangeliet. Salmebogen indeholder noder med eksempler på de relevante melodiforløb, og der er også noder i det anførte citat. Det forudsættes klart, at præsten har sunget evangelieteksten, og at læsningen er foregået fra alteret.

I forbindelse med prædikenen anføres det i overensstemmelse med Kirkeordinansen, at præsten skal indlede med en formaning til bøn (Thomissøn 1569, blad Aaa $\mathrm{v}^{\mathrm{r}}$ ). Men der anføres ikke noget om en evangelielæsning fra prædikestolen. Efter min vurdering kan man dog ikke bruge det til at konkludere, at der ikke har været nogen evangelielæsning fra prædikestolen. Salmebogen er en brugsbog, og den er primært beregnet til degnen og folket, ikke til præsten. I omtalen af nadverritualet anføres eksempelvis hverken Fadervor eller indstiftelsesordene, men der henvises til tekster og noder i alterbogen, som er præstens bog.

Kort tid efter Thomissøns salmebog udkom Niels Jesperssøns graduale i $1573 .{ }^{12}$ Gradualet er primært beregnet til at bruges ved bykirker med tilknyttede latinskoler og indeholder især de gudstjenesteled, der kunne synges på latin, herunder især introitus og halleluja. Gradualet indeholder ikke nogen egentlig beskrivelse af højmessens gang, men to bisætninger viser formentlig, at prædiketeksten normalt blev læst fra prædikestolen. Ved gudstjenesten juledag synges et prædikestolsvers tre gange, "før end texten oplæssis" (Jesperssøn 1573, 53). Tilsvarende anføres ved påskegudstjenesten (199). Jeg formoder, at det ikke er en særregel for højtidsgudstjenesterne, men en generel regel. ${ }^{13}$

I de danske kilder fra perioden har jeg ikke fundet begrundelser eller uddybende argumenter for evangelielæsningernes placering og funktion. Men det kan man i den svenske højmesseordning, hvor man har haft en tilsvarende dobbelt evangelielæsning fra 1571 til 1811 ifølge de officielle kirkeordninger og håndbøger. I den svenske kirkeordning fra 1571 blev evangeliet først læst fra alteret, og derefter

12. Niels Jesperssøn. Gradval. En Allmindelig Sangbog ... effter Ordinantzens lydelse. Kjøbenhaffn: Laurentz Benedicht 1573. Moderne faksimileudgave: Niels Jesperssøns Graduale 1573. Udg. af Dansk Organist- og Kantorsamfund og Samfundet Dansk Kirkesang. København: Dan Fog Musikforlag 1986.

13. Men det kunne på den anden side godt være en særregel, fordi evangeliet på de store helligdage i denne periode blev sunget på latin. 
blev det gentaget på prædikestolen "på thet folket teste bätter må minnas orden, och teste snarare merckia huru hwart stycke för sigh $\mathbf{j}$ vthlägningenne warder förhandlat”. ${ }^{14}$ En tilsvarende begrundelse for den dobbelte evangelielæsning i dansk sammenhæng forekommer ret sandsynlig.

En anden mulig forklaring på den dobbelte evangelielæsning kan være, at det er en fortsættelse af en senmiddelalderlig tradition. I et eller andet omfang blev der også prædiket på dansk i senmiddelalderen. Når messens perikoper havde været læst på latin, var der brug for en oversættelse af evangelieperikopen til dansk forud for prædikenen. $\mathrm{Og}$ det kan være en sådan tradition, der er blevet fortsat efter reformationen, selv om evangelieperikopen nu var blevet messet på dansk fra alteret.

Et eksempel på, at der før reformationen har eksisteret danske oversættelser af bibelperikoperne til kirkeårets søn- og helligdage, findes i Christiern Pedersens postille fra 1515. Den går almindeligvis under navnet "Jærtegnspostille", men det er i nogen grad et misvisende navn, fordi bogen også indeholder en dansk oversættelse af bibelperikoperne til kirkeårets søn- og helligdage. Karakteristisk er den originale titel på postillen: Alle Epistler oc Euangelia som lesiss alle Søndage om aared, sammeledis Jule dag, Paaske dagh, Pingetz dag, meth deriss udtydning oc glose oc eth Jertegen til huer dag ... ${ }^{15}$ Titlen viser, at den danske bibeloversættelse var et vigtigt punkt i postillen. Og oversættelserne ville kunne bruges i forbindelse med danske prædikener ved latinske gudstjenester før reformationen.

\section{Dobbelt evangelielæsning i Kirkeritualet 1685}

Efter enevældens indførelse i 1660 blev den overordnede lovgivning samlet i Danske Lov fra 1683. De kirkeretslige bestemmelser findes i lovens anden bog "Om Religionen og Geistligheden", hvor der er et kapitel 4 om gudstjenesten og prædikenen og et kapitel 5 om sakramenterne dåb og nadver, samt skriftemål. Der findes dog ikke detaljerede bestemmelser om højmesseordningen i Danske Lov. I stedet henvises til liturgisk praksis i Vor Frue Kirke i København og til det forordnede ritual (Danske Lov 2-4-4).

14. Citeret fra Carl Henrik Martling. Svensk liturgihistoria. Stockholm: Verbum 1992, 216.

15. Første udgave trykt i Paris 1515. Moderne udgave i: Christiern Pedersens Jartegns-Postil, I. Vinterparten, II. Sommerparten, udg. af C.J. Brandt \& R.Th. Fenger. Kjøbenhavn: Gyldendal 1850-1851. 
Det forordnede ritual udkom to år senere under titlen: Danmarks og Norgis Kirke-Ritual. ${ }^{16}$ Ritualet er udarbejdet af en kommission, hvor den afgørende person har været biskop Hans Bagger. Efterfølgende er udkastet blevet gennemgået af en revisionskommission og endeligt godkendt i 1685 af kong Christian den Femte. ${ }^{17}$

De afgørende bestemmelser om højmessen findes i Kirkeritualets første kapitel, der handler om gudstjenesten i kirken (Kirke-Ritual 1985, 9-26). Gudstjenestekapitlet er underinddelt i to artikler: første artikel handler om søndage og helligdage, og anden artikel om fredage og onsdage. Og på søndagene er der to forskellige former. Ved den tidlige gudstjeneste, froprædikenen, er der hverken messe fra alteret eller nadver, mens der ved højmessen bliver messet fra alteret og holdes nadver, hvis der er nadvergæster. Søndagens højmesse er altså kun én ud af flere forskellige gudstjenesteformer.

I bestemmelserne om søndagens højmesse er det tydeligt, at der er to evangelielæsninger; den første bliver messet fra alteret, og den anden bliver læst fra prædikestolen. Efter at epistlen er blevet messet fra alteret, synges en kort salme, der stemmer overens med epistlen. Derefter kommer evangelielæsningen fra alteret:

Der paa vender Præsten sig atter om til Folket og med høj Røst og lydelig Stemme efter sædvane synger Evangelium med denne Begyndelse:

Dette hellige Evangelium skriver Evangelisten N.N.

Choret svarer: Gud være lovet for sit gladelige Budskab.

Eller og: Priis og ære være dig HERRE!

Der paa synger hand det gandske Evangelium, som hører til Dagen, og naar det er Ende, vender hand sig til Alteret igien og begynder:

Vi tro allesammen paa een Gud etc.

Hvilken siden af Menigheden og paa Orgelverket forfølgis indtil Enden.

Efter Evangelium er udsiunget for Alteret, ringis udi Prædikestolen

med de smaa Klokker, ligesom sædvanligt er (Kirke-Ritual 1985, 14).

I forhold til Kirkeordinansen 1539 repræsenterer Kirkeritualet 1685 ikke noget afgørende nyt på dette punkt. Der er grundlæggende ikke tale om et nybrud eller en afgørende forandring, men om en ajourføring og kodificering af praksis, som det havde udviklet sig siden 1539.

16. Danmarks og Norgis Kirke-Ritual. Kiøbenhavn: Joachim Schmedtgen 1685. Moderne udgave: Danmarks Og Norgis Kirke-Ritual, 1685-1985. Genudgivet af Udvalget for Konvent for Kirke og Theologi. Skarrild 1985. [Forkortet: Kirke-Ritual 1985].

17. Jf. Borregaard 1953, som inddrager et manuskript med Hans Baggers egne ændringsforslag til Kirkeritualet. 
Der findes fortsat ikke nogen egentlig højmesseordning med alle de relevante faste tekster. Kirkeritualet 1685 er heller ikke en egentlig liturgisk brugsbog, men snarere en samling af love og bestemmelser.

Kirkeritualet 1685 følges op af en revideret alterbog i 1688 med forord af Hans Bagger: Forordnet Alterbog udi Danmark og Norge. ${ }^{18}$ Men også alterbogen 1688 holder sig i hovedsagen til det spor, som blev lagt af Palladius i 1556.

Der er ifølge Kirkeritualet fortsat to perikoper fra Bibelen: epistlen og evangeliet. Og evangelielæsningen finder sted fra alteret, ligesom epistlen. Det fremgår nu helt tydeligt, at evangeliet synges (messes). Dialogen forud for evangelielæsningen, som kun var antydet i Kirkeordinansen, er nu anført med tekst for både præst og kor (menigheden). Teksten er i hovedtræk den samme som i Vormordsens Messehåndbog $1539 \mathrm{og}$ Thomissøns salmebog 1569. Derimod findes der påfaldende nok ikke noder i de liturgiske bøger fra denne periode. Der henvises blot til sædvane.

En nyskabelse i forhold til Kirkeordinansen er, at der henvises til en klokkeringning "ligesom sædvanligt er" efter evangelielæsningen fra alteret. Konteksten i Kirkeritualet tyder på, at meningen med klokkeringningen er at fremhæve evangelielæsningen. ${ }^{19}$

Efter evangelielæsningen følger trosbekendelsen. Det ligger nu helt fast, at trosbekendelsen synges i form af en salme. Men rækkefølgen er der ikke ændret på. Trosbekendelsen følger fortsat umiddelbart efter evangelielæsningen fra alteret. Det er nu ikke længere en mulighed på særlige højtidsdage eller i bykirker med latinskoler at synge Nikænum på latin med gregorianske noder.

Når præsten er gået på prædikestolen, synges ifølge Kirkeritualet først en kort salme over søndagens evangelium. Og derefter følger anvisningen om, hvad præsten skal gøre på prædikestolen.

Præsten, eller hvo, som Prædiker skal allerførst formane Folket til Bøn og

Paakaldelse om Guds hielp i denne hellige Forrretning og der paa læse, som sædvanligt, HErrens Bøn: Fader vor du som est i Himmelen etc.

Dernest skal hand tydeligen oplæse Texten, som skal forklaris, og siden klarligen udlegge den, dog ikke over en Time (Kirke-Ritual 1985, 15).

18. [Bagger, Hans]. Forordnet Alterbog udi Danmark og Norge. Kiøbenhavn: Joachim Schmedtgen 1688.

19. Jf. Urban Schrøders noter i Kirke-Ritual 1985, 148; samt Borregaard 1953, 110. En anden tolkning af ringningen findes hos Helge Fæhn. Gudstjenestelivet i Den norske kirke - fra reformationen til våre dager. Oslo: Universitetsforlaget 1994, 54. Fæhn går ud fra, at ringningen skulle signalere, at nu kom det vigtigste i gudstjenesten, nemlig prædikenen, men omtaler dog også muligheden af, at ringningen oprindelig skulle fremhæve det første højdepunkt i messen, nemlig evangelielæsningen. 
Det er helt tydeligt, at evangelielæsningen gentages fra prædikestolen, selv om den allerede har været messet fra alteret. De liturgiske og praktiske omstændigheder er dog forskellige ved de to evangelielæsninger. Fra alteret messes evangeliet, og præsten er iført messeklæder. På prædikestolen læses teksten, og præsten er ikke længere iført messehagel.

I forhold til Kirkeordinansen udvider Kirkeritualet indledningen på prædikestolen med salmesang og Fadervor, men gentagelsen af evangelielæsningen på prædikestolen ser ud til at være en fortsættelse af regler og praksis siden 1540. Der er på dette punkt ikke tale om en nyskabelse. ${ }^{20}$ Det gælder formentlig også nogle af udvidelserne. Om Fadervor til indledning på prædikestolen anfører Kirkeritualet, at den læses som sædvanligt. Og de salmevers, som Kirkeritualet anfører efter Fadervor en stor del af kirkeåret, er de samme som i Thomissøns salmebog og i Jesperssøns graduale. ${ }^{21}$

\section{Kritik i 1700-tallet af dobbelt evangelielasning}

I princippet har Kirkeritualets regler om en dobbelt evangelielæsning været gældende frem til indførelsen af anden tekstrække i slutningen af 1800 -tallet. Og her fik den dobbelte evangelielæsning en fortsættelse i en anden form. Det var ikke længere den samme evangelieperikope, der blev læst to gange, men to forskellige evangelieperikoper.

Ordningen med en dobbelt evangelielæsning begyndte dog allerede at blive kritiseret i 1700-tallet. I første omgang kan kritikken betragtes som en indirekte bekræftelse af, at ordningen med den dobbelte evangelielæsning var i faktisk brug i 1700-tallet - eller i det mindste, at reglerne blev betragtet som gældende. Kritikken banede vej for en udbredt brug af "halv messe" i 1800-tallet. I den halve messe var der kun én evangelielæsning, og den foregik fra prædikestolen i tæt sammenhæng med prædikenen.

En markant repræsentant for den tidlige kritik af den dobbelte evangelielæsning i Kirkeritualet er biskop Peder Hersleb, som i 1735 efter anmodning indsendte et udførligt votum med kritik af den eksisterende ordning samt forslag til ændringer. ${ }^{22}$ Han spørger kritisk:

20. Jf. Borregaard 1953, 111-112; samt Urban Schrøders noter i Kirke-Ritual 1985, 148-149.

21. Jf. Sørensen 1969, 78.

22. Udgivet af P.G. Lindhardt. Kirke-Ritualet og pietismen. Biskop Peder Herslebs betenkning over Danmarks og Norgis Kirke-Ritual af 1685. København: Akademisk Forlag 1986. 
... hvorfor skal det Evangelium, som tydelig og forstaaelig oplæses paa Prædikke-Stolen, og der forklares, dog synges først for Alteret? hvor sielden Meenigheden kand høre hvad der siunges, naar Kjerken er stoer og Præsten har ikke des sterckere Røst, da end Sangen gjør det u-forstaaelig, om end Røsten er god? (Lindhardt 1986, 21).

Hersleb er kritisk over for den dobbelte evangelielæsning og foreslår den afskaffet. Indirekte bevidner han, at den dobbelte evangelielæsning fortsat er almindelig praksis i første del af 1700-tallet. Den plads for evangelielæsningen, som Hersleb ser ud til at foretrække, er oplæsningen fra prædikestolen i tæt tilknytning til prædikenen.

Generelt er han kritisk over for, at præsten messer. Han anser det for en papistisk uorden og vil foretrække, at præsten nøjes med at læse. Og det kunne godt se ud til, at han foretrak, at slet ikke nogen af læsningerne foregik fra alteret, men at præsten i stedet for at messe den traditionelle epistel fra alteret læste fra kordøren først et kapitel fra Det Gamle Testamente og derefter et kapitel fra Det Nye Testamente (Lindhardt 1986, 22).

Herslebs forslag ser ud til at befinde sig på to niveauer. Et ideelt niveau med forslag til radikale ændringer, og et jordnært niveau med mindre justeringer. På det sidste niveau foreslår han, at evangelielæsningen bør indledes med salutation før evangelieintroduktionen, sådan som det er almindelig praksis. Denne salutation er ikke omtalt i Kirkeritualet. Og man kan også lige så godt udelade evangeliesvaret "Priis og ære være dig Herre", for det er man holdt op med at bruge, selv om det står som en mulighed i Kirkeritualet (Lindhardt 1986, 30 ). Her ser han ud til at forudsætte, at der fortsat er en evangelielæsning fra alteret, og formentlig også, at den bliver messet.

I sidste del af 1700-tallet kritiserer Henrich Ussing, at præsterne skal spilde tiden med at messe kollekten og de bibelske læsninger fra alteret. ${ }^{23}$ Han anser det for at være en levning fra den ørkesløse katolske gudstjeneste. Men ifølge de gældende love er det en pligt for præsterne at messe (synge), og der er ingen dispensationsmuligheder. Han foreslår derfor, at lovene bliver ændret, sådan at præster ikke længere har pligt til at messe. Og folk er flere steder allerede mere eller mindre blevet vant til det, fordi en del præster er begyndt at holde "halv Messe". Så det vil nok ikke blive svært at vænne dem til, at der slet ikke bliver messet. Ussing skriver:

23. Henrich Ussing. Kirkeforfatningen i de kongelige danske Stater, med dens vigtigste Fordele og Mangler samt muelige Forbedringer, 4. Deel, 1. Bind. Sorøe: J. Lindgrens Enke 1788. 
Da endeel Præster ogsaa allerede - vi vil antage altid, for at vinde Tid til noget vigtigere - saa temmelig har begyndt at holde halv Messe isteden for heel, og mange Dage ganske at udelade den, skiønt Lovene just ikke give Frihed til nogen af Delene (Rit. pag. 11), saa vil det heller ikke nu være saa vanskeligt at vænne Folket til at ganske undvære den, naar det bliver Alvor, og det bør blive Alvor; ... (Ussing 1788, 366).

Begrebet "halv Messe", der her bliver brugt af Ussing i sidste del af 1700-tallet, har måske sin baggrund i en formulering i Kirkeritualet. Ifølge Kirkeritualet skal der på søndage og helligdage holdes "fuld Messe til Høj-Prædiken” (Kirke-Ritual 1985, 12). Denne formulering skyldes måske, at der allerede i 1685 var nogen, der ikke holdt fuld messe, og at det derfor var nødvendigt at indskærpe, at der skal holdes fuld messe. ${ }^{24}$

Opslaget om "messe” i Matthias Moths ordbog, der dækker det danske sprog omkring 1700, peger i retning af, at "halv messe" var et kendt fænomen allerede omkring år $1700 .{ }^{25}$ Ordbogen definerer fuld messe som en gudstjeneste, hvor både epistel og evangelium messes fra alteret, mens det ved en halv messe (missa dimidiata) kun er epistlen, der messes fra alteret.

De officielle regler fastholder i 1700-tallet reglen fra Kirkeritualet om, at der er to evangelielæsninger, men praksis er i færd med at ændre sig, sådan at der kun er én evangelielæsning, og den er fra prædikestolen.

\section{Halv messe i 1800-tallet og ingen evangelielæsning fra alteret}

I 1798 udkom Evangelisk-kristelig Psalmebog, som mere uformelt kaldes Balles salmebog. Hvor Kingos salmebog fra 1699 tydeligt knyttede sig til højmesseordningen i Kirkeritualet og var en del af en del af den samlede pakke, har Balles salmebog 100 år senere et mere frit forhold til Kirkeritualets højmesseordning og understøtter ikke ordningen i samme omfang som Kingos salmebog.

Det kommer klart til udtryk i et opfølgende kongeligt reskript fra 18. juni 1802 om salmevalget i de menigheder, som bruger Balles sal-

24. Jf. Borregaard 1953, 169, der gør opmærksom på, at Hans Bagger allerede ved et landemode i 1692 var nødt til at indskærpe, at der altid skal være fuld messe, og at både epistel og evangelium skal læses fra alteret.

25. Matthias Moth (1649-1719) skrev en ordbog, der ikke blev trykt, men er bevaret i 62 håndskrevne foliobind. Det Danske Sprog- og Litteraturselskab har gjort værket digitalt tilgængelig fra https://mothsordbog.dk (set 01.12.2020). 
mebog. ${ }^{26}$ Formelt set vedrører reskriptet kun salmevalget, men i realiteten ændrer det på højmesseordningen på nogle vigtige punkter, herunder trosbekendelsens placering og evangelielæsningens placering.

Den indledende kyriesalme fra Kirkeritualet erstattes ifølge reskriptet af en almindelig indgangssalme (nr. 371-378). Og derefter intonerer præsten fra alteret enten trossalmen (nr. 1, Vi troe, vi Alle troe paa Gud) eller gloriasalmen (nr. 3, Alene Gud i Himmerig), som derefter fortsættes af menigheden. De to salmer bruges skiftevis den ene og den anden søn- og helligdag.

Trosbekendelsen har altså efter dette reskript ikke længere sin faste plads efter evangelielæsningen fra alteret. Den er blevet til en næsten almindelig salme med et nummer, og den bliver kun brugt hver anden gang, der holdes gudstjeneste. En af årsagerne til denne regel er formentlig, at reskriptet også ophæver forpligtelsen til altid at holde "fuld Messe" og messe evangeliet fra alteret. Dermed mister trosbekendelsen sit tilknytningspunkt i højmessen som opfølgning eller afslutning af evangelielæsningen. Reskriptets punkt 4 og 5 lyder:

... 4) at Evangelium, naar fuld Messe holdes, derpaa skulde messes for Alteret, og derefter synges Psalmen No. 235 [Dig bede vi, o hellig Aand]; med sidste Vers af Psalmen maatte Præsten gaa paa Prædikestolen; 5) men at, naar fuld Messe bortfalder (paa det at Tid kunde levnes efter Prædikenen til Catechisation, Communion og ministeriale Forretninger), maatte synges en af Præsten valgt Psalme, som ikke maatte være kortere end 2 Vers, da Sangeren ligeledes fremtræder i Chordøren for at forelæse det 1ste Vers, og med det sidste Vers gaar Prædikanten paa Prædikestolen ... (Fogtman 1810, 621-622).

Ifølge reskriptet er der altså valgmulighed mellem at holde fuld messe, hvor evangeliet messes fra alteret, og ikke holde fuld messe. Reskriptet beskriver ikke direkte, hvad det er, der bortfalder, når ikke holdes fuld messe, men læst i sammenhængen kan der næppe være tvivl om, at det er evangelielæsningen fra alteret, der bortfalder. Under alle omstændigheder læses evangeliet fra prædikestolen forud for prædikenen, og denne placering er på vej til i 1800-tallet at blive evangelielæsningens primære placering i højmessen.

26. Rescript (til Biskoppen over Sjellands-Stift), ang. Gudstjenesten, hvor den evangelisk-christelige Psalmebog i dette Stifts menigheder er eller vorder indført. Aftrykt i: Laurids Fogtman. Kongelige Rescripter, Resolutioner og Collegialbreve for Danmark og Norge, udtogsvis udgivne i chronologisk Orden, VI. Deel, 11. Bind, 18011802. 1810. København: Gyldendal, 621-622. Reskriptet fik også gyldighed for de andre stifter. 
Reskriptet fra 1802 er ikke en ophævelse af bestemmelserne i Kirkeritualet 1685, så den overordnede norm er fortsat, at evangeliet både messes fra alteret og læses fra prædikestolen. Formelt set er bestemmelserne i reskriptet knyttet til brugen af Balles salmebog, men i praksis betyder reskriptet en officiel godkendelse af, at man i det meste af 1800-tallet kunne nøjes med en halv messe, hvor præsten fra alteret i højmessens første del kun messede kollekten og epistlen. Denne praksis med halv messe betød, at der i højmesseordningen som helhed opstod et skel mellem den liturgiske messen fra alteret og oplæsningen af prædiketeksten fra prædikestolen.

Forskellige spredte bemærkninger tyder på, at den halve messe var en udbredt praksis i 1800-tallet. Og det er først i forbindelse med indførelsen af anden tekstrække i slutningen af århundredet, at man fra officielt hold forsøger igen at afskaffe den halve messe og indskærpe Kirkeritualets bestemmelser om, at der ved højmessen skal være en evangelielæsning fra alteret.

I 1832 udsendte kantoren ved Vor Frue Kirke i København, Johannes Wiberg, en håndbog for præster om at messe: Messe-Melodier. ${ }^{27} \mathrm{I}$ hovedtræk forudsætter han en højmesseordning i overensstemmelse med reskriptet fra 1802. Efter hilsenen messer præsten kollekten og epistlen. Derefter synges højmessens hovedsalme, og præsten fortsætter fra alteret med at messe dagens evangelium. Når evangeliet er messet, vender præsten sig igen mod alteret, afføres messeklæderne og forlader alteret. Men Wiberg forudsætter, at der også er mulighed for en halv messe:

Messen för Prædiken kan være enten saakaldet Heel- eller Halv-Messe.
Ved Heel-Messe forstaaes, naar baade Collect, Epistel eller Lectie og
Evangelium messes; ved Halv-Messe derimod, naar allene Collect og
Epistel eller Lectie messes, hvilket sidste især finder sted i Landsbye-
kirker. Hvor der kun er Halv-Messe, fölger det af sig selv, at Præsten,
efterat Collecten og Epistelen eller Lectien er messet, forlader Alteret
(Wiberg 1832, 18).

Messehåndbogen har ikke nogen juridisk gyldighed, men kan på dette punkt opfattes som en god beskrivelse af almindelig praksis i første del af 1800-tallet.

Fra sidste del af 1800-tallet foreligger en revideret håndbog $\mathrm{i}$ at messe udgivet af Viggo Sanne, der også var kantor ved Vor Frue Kirke. ${ }^{28}$ På dette tidspunkt (i 1879) forudsættes fortsat, at messen før

27. Johannes Wiberg. Messe-Melodier. Kjøbenhavn: Birck \& Comp. 1832.

28. Viggo Sanne. Messebog. Kjøbenhavn: F. Borchorsts Forlag 1879. 
prædiken kan være enten en helmesse eller en halvmesse. Om halvmessen skriver Sanne, at den "især finder Sted til Froprædiken i Hovedstadens Kirker og til Højmesse i Landsbykirker” (Sanne 1879, 9).

En kilde af en anden type er biskop Mynsters forslag i 1839 til alterbog og kirkeritual. ${ }^{29}$ Forslaget blev ikke autoriseret og kan således ikke direkte bruges som kilde. Men forslaget ser på flere punkter ud til at afspejle samtidig liturgisk praksis. Forslaget til salmevalg, hvis man bruger Balles salmebog, er i alt væsentligt identisk med reskriptet fra 1802. Hertil hører, at man efter indgangssalmen hver anden søn- og helligdag synger trossalmen (nr. 1, Vi troe, vi Alle troe paa Gud). Trossalmen har altså ikke længere en fast plads efter evangelielæsningen, og den skal kun synges hver anden søndag.

Strukturen i den første del af højmessen ifølge Mynsters forslag svarer til den såkaldte halve messe. Der er kun én læsning fra alteret, og det kan være enten epistlen eller evangeliet, afhængigt af hvad der prædikes over. Når der prædikes over evangeliet, messes epistlen fra alteret. $\mathrm{Og}$ når der prædikes over epistlen eller den tredje prædiketekst, messes evangeliet fra alteret (Mynster 1839, Kirke-Ritual, 6-8, pkt. 10). Prædiketeksten læses kun fra prædikestolen. Det fremgår af Mynsters bemærkninger, at han anser denne ordning for at være i overensstemmelse med udbredt praksis i samtiden:

Den saakaldte Fuld-Messe, eller at baade Epistel og Evangelium messes for Prædiken, har jeg foreslaaet at skulle bortfalde. Den bruges nu vel kun i Kiøbenhavns Kirker, og da den i sig selv er trættende, og kun meget faa Tilhørere ere tilstede derved, saa synes den ganske at burde udelades, hvorved ogsaa noget mere Tiid vil vindes for Skriftemaalet om Morgenen (Mynster 1839, Bemærkninger, 36, $₫ 10$ ).

Mynsters forslag afspejler formentlig en udbredt holdning i samtiden. Det primære er, at prædiketeksten bliver læst fra prædikestolen i tæt tilknytning til prædikenen. Og selv om bibellæsningen fra alteret efter Mynsters forslag i mange tilfælde vil være en evangelielæsning, har evangelielæsningen som sådan ikke nogen bestemt plads i højmesseordningen. Det kan være fra prædikestolen, eller det kan være fra alteret.

Mynsters forslag udløste, at professor C.T. Engelstoft året efter, i 1840, udgav en bog om liturgiens historie i Danmark. ${ }^{30}$ Bogen var på

29. [Jacob Peter Mynster]. Udkast til en Alterbog og et Kirke-Ritual for Danmark. Kiöbenhavn: Schultz 1839. Forfatternavn er ikke anført på titelbladet; udkastet består af tre dele med hver deres særskilte sidenummerering.

30. C.T. Engelstoft. Liturgiens eller Alterbogens og Kirkeritualets Historie i Danmark. Kjøbenhavn: Reitzels Forlag 1840. 
samme tid en liturgihistorie og et indlæg i den aktuelle debat. Jeg vil her forsøge at bruge bogen som kilde til liturgisk praksis i Danmark i 1830 'erne.

Engelstoft omtaler, at Balles salmebog formentlig har foranlediget en stor omvæltning af højmesseordningen:

Ved den evangeliske Psalmebog er formodentlig den store Omveltning i denne Deel af Messen foranlediget, at een af de almindelige Psalmer Nr. 1 og Nr. 3 bliver sunget mellem Epistel og Evangelium, samt at Psalmen "før Prædiken" staaer alene mellem Evangelium og Prædiken (Engelstoft 1840, 72).

I det anførte citat forudsætter Engelstoft, at både epistlen og evangeliet messes fra alteret forud for prædikenen. Kirkeritualet 1685 foreskriver, at evangelielæsningen fra alteret bliver efterfulgt af trossalmen, men det er ikke længere praksis omkring 1840. Her synger man i stedet en salme før prædikenen, og det er formentlig en frit valgt salme.

Trossalmen, som er nr. 1 i Balles salmebog, synges nu efter epistlen og inden evangeliet, vekslende med gloriasalmen (nr. 3). Denne placering er formentlig foranlediget af reskriptet fra 1802, men er ikke i overensstemmelse med reskriptet, for her skulle man skifte mellem de to salmer efter indgangssalmen og inden kollekt og epistel. Man har åbenbart i denne periode ikke længere en fælles opfattelse af, at trosbekendelsen hører hjemme et bestemt sted i højmesseordningen. Trossalmen er i stedet på vej til at blive en almindelig salme, som kan synges forskellige steder i formessen eller helt kan udelades.

Engelstoft gør også opmærksom på, at præsterne i løbet af 1700-tallet er begyndt at forkorte messen til dagligt brug og nøjes med at holde "fuld Messe", når der er brug for at holde festgudstjeneste og gøre noget særligt ud af situationen. Reglen er blevet gjort til undtagelsen (Engelstoft 1840, 87). Engelstoft bruger - så vidt jeg kan se - ikke begrebet "halv messe". Men han ser ud til at forudsætte, at den normale praksis er, at præster nøjes med en halv messe, hvor man undlader at messe evangeliet fra alteret.

Fra slutningen af denne perioden, på overgangen til indførelsen af anden tekstrække, findes der en lille liturgisk håndbog af provst C.C.S. Cederfeld de Simonsen..$^{31}$ Han beskriver i håndbogen, der er beregnet for kirkegængere og menighedsmedlemmer, gudstjenestens

31. C.C.S. Cederfeld de Simonsen. Kirkeaaret, Gudstjenesten og de kirkelige Handlinger, en Haandbog for Kirkegjangere og Menighedsmedlemmer. Kjøbenhavn: Th. Lind 1885. 
gang, når der holdes "fuld Messe". I en note omtaler han, at man i mange kirker nøjes med at holde "halv Messe":

I de fleste Landsbykirker og i adskillige Kjøbstadskirker holdes der i Regelen kun halv Messe undtagen på de store Høitidsdage. Der bliver da kun messet eet Skriftafsnit fra Alteret og ikke sjælden udeladt en af Psalmerne før Prædiken (Cederfeld 1885, 6, note 1).

Hans beskrivelse af den fulde messe omkring år 1885 svarer ret nøje til den ordning, som Engelstoft forudsatte omkring år 1840. Imellem epistlen og evangeliet synges enten trossalmen ( $\mathrm{Vi}$ troe, vi alle troe paa Gud), eller jubelsalmen (Alene Gud i Himmerig), som intoneres af præsten og fortsættes af menigheden. Evangeliet messes af præsten for alteret, indledt med den sædvanlige dialog. Inden prædikenen synges dagens hovedsalme (Cederfeld 1885, 6-7).

I et afsnit med anmærkninger inddrager han blandt andet reskriptet fra 1802. Han omtaler, at ifølge reskriptet skulle "Troessalmen" eller "Jubelsalmen" synges søndag efter søndag mellem indgangssalmen og kollekten. "Efterhaanden har imidlertid den Skik fæstnet sig, at den ene eller den anden af dem synges efter Epistelens Oplæsning, forinden Evangeliet bliver forelæst" (Cederfeld 1885, 37).

Højmessens hovedsalme, som undertiden kaldes "Høimessepsalmen", synges umiddelbart før prædikenen og slutter sig i almindelighed til dagens evangelium. Ifølge reskriptet fra 1802 skulle hovedsalmen synges imellem epistlen og evangeliet, men denne skik er ifølge Cederfeld forlængst gået af brug på dette tidspunkt i slutningen af 1800-tallet (Cederfeld 1885, 38).

Cederfeld giver en god beskrivelse af situationen, da anden tekstrække blev indført i 1885. Evangeliet læses kun fra alteret, når der holdes fuld messe, og det er langt fra i alle kirker, at man gør det regelmæssigt. Trossalmen synges højest hver anden gang, der er gudstjeneste, og synges i givet fald efter epistlen.

To tekstrækker og to forskellige evangelielæsninger (1885-1992)

I slutningen af 1800-tallet blev der indført en anden tekstrække efter forslag fra nogle præstekonventer. ${ }^{32}$ Der var to faser i indførelsen af anden tekstrække. En første fase efter 1885, hvor de gamle evangelier

32. Jf. Henning Nielsen. "Rids af 2. Textrækkes Tilblivelseshistorie". Stiftsbog og landemode-akt for Lolland-Falsters Stift 1985, 23-40. 
opretholdt eneret ved altertjenesten, og en anden fase efter 1897, hvor de to tekstrækker blev sidestillet, og hvor den udbredte halve messe blev forsøgt afskaffet. Reglerne fra den første fase i 1885 er ikke mere gyldige, mens reglerne fra den anden fase ikke er blevet ophævet og stadigvæk kan bruges.

De nye prædiketekster til anden række blev i første omfang i 1885 trykt i et særskilt tillæg til alterbogen: Anden Rakke. Pradiketexter til Kirkeaarets Søn- og Helligdage. ${ }^{33}$ Bogen indeholdt kun de bibelske læsninger til anden række, en epistel og et evangelium for hver søn- og helligdag; så den skulle bruges sammen med den almindelige alterbog. Reglerne for, hvordan de nye tekster skulle bruges, fandtes ikke i bogen med prædiketeksterne, men blev kun formuleret i en bekendtgørelse af 2 . februar $1885 .{ }^{34}$

Som udgangspunkt gik bekendtgørelsen ud fra, at der blev holdt "fuld Messe", men det var fortsat tilladt at holde halv messe. Ved fuld messe i forbindelse med en højmesse var der to evangelielæsninger ligesom i Kirkeritualet 1685. Den første blev messet fra alteret, og den anden blev læst fra prædikestolen forud for prædikenen.

Det evangelium, der blev messet fra alteret, var under alle omstændigheder evangeliet fra den gamle række. Det blev fastsat som en regel, at "De gamle Evangelier skulle have Eneret ved Altertjenesten". Når der blev prædiket over den nye evangelietekst fra anden række, var det efter de nye regler to forskellige evangelier, der blev læst. Men når der blev prædiket over det gamle evangelium, blev den samme evangelietekst læst to gange.

De nye regler trådte i kraft fra 1. søndag i advent 1885, og her skulle ved fuld messe bruges følgende perikoper: fra alteret ny epistel og gammelt evangelium, fra prædikestolen nyt evangelium. Det følgende kirkeår, fra 1. søndag $\mathrm{i}$ advent 1886, var perikoperne: fra alteret gammel epistel og gammelt evangelium, fra prædikestolen gammelt evangelium.

Bekendtgørelsen indeholdt også regler om fremgangsmåden ved halv messe. Det fremgår klart, at når der prædikes over de nye evangelier, skal det gamle evangelium læses fra alteret. I dette tilfælde bliver der altså ikke læst nogen epistel. Bekendtgørelsen ser også ud til at foreskrive, at det gamle evangelium ved halv messe skal læses som eneste tekst fra alteret, når der det følgende år prædikes over det gamle evangelium.

33. Anden Rakke. Pradiketexter til Kirkeaarets Søn- og Helligdage. Kjøbenhavn: Gyldendalske Forlag 1885.

34. Bekjendtgiørelse om Autorisering af en ny Række Prædiketexter. Aftrykt i: Love og Expeditioner vedkommende Kirke- og Skolevasen 1884-86, 164-165. 
Bekendtgørelsen indeholder kun en beskrivelse af reglerne. Der er ikke nogen begrundelse eller angivelse af hensigten. Det primære formål er naturligvis, at der kommer nogle flere prædiketekster, og at der ikke skal prædikes over de samme tekster år efter år. Men det ser ud til, at der samtidigt er et ønske om at gengive det gamle evangelium sin oprindelige plads som et højdepunkt i højmessens første del, i liturgien fra alteret før prædikenen. ${ }^{35}$

Et nyt træk ved reglerne i forbindelse med indførelsen af anden tekstrække er, at der indirekte indføres en skelnen mellem den liturgiske evangelielæsning fra alteret, hvor præsten er iført messehagel og messer, og den homiletiske oplæsning af prædiketeksten fra prædikestolen, hvor præsten ikke længere er iført messehagel. En sådan distinktion eksisterede ikke på samme måde i Kirkeordinansen og Kirkeritualet, hvor evangelielæsningen fra alteret på samme tid var liturgisk læsning og prædiketekst; og det var kun af praktiske og pædagogiske grunde, at evangelielæsningen blev repeteret fra prædikestolen i forbindelse med prædikenen. Evangelielæsningen fra prædikestolen blev primært betragtet som en del af prædikenen og ikke som et selvstændigt liturgisk led i højmessen.

Matzen og Timms Haandbog i den danske Kirkeret fra 1891 er skrevet i den første fase af indførelsen af anden tekstrække, og de refererer i deres beskrivelse af gudstjenestens orden blandt andet til bekendtgørelsen af 2. februar 1885. ${ }^{36}$ De omtaler forskellen på "fuld Messe” og "halv Messe". Fuld messe defineres som en gudstjeneste, hvor præsten i overensstemmelse med Ritualet messer: "1) Kollekten; 2) Epistlen eller Lektien; 3) Evangeliet” (Matzen \& Timm 1891, 411). De er opmærksomme på, at man mange steder har tilsidesat loven og nøjes med en halv messe, sådan som det forudsættes som en mulighed i reskriptet fra 1802. Men selv om de altså selv henviser til reskriptet fra 1802, betragter de det ikke som en lovliggørelse. Og tilsyneladende betragter de det heller ikke som en lovliggørelse af den halve messe, at den indirekte er omtalt og accepteret i bekendtgørelsen om anden tekstrække fra 1885, som er udarbejdet under henvisning til en kongelig resolution af 28 . januar 1885 .

\section{Anden fase fra 1897 med to forskellige evangelielasninger}

Bestemmelserne fra 1885 om de gamle evangeliers eneret ved altertjenesten blev ophævet ved en ny kongelig resolution i 1897 og of-

35. Jf. Nielsen 1985, 34-38, hvor der redegøres for forhandlingerne i Det kirkelige råd i 1884 om indførelse af anden tekstrække.

36. Henning Matzen \& Johannes Timm. Haandbog i den danske Kirkeret. Kjøbenhavn: Schultz 1891. 
fentliggjort ved en bekendtgørelse af 29. januar 1897. ${ }^{37}$ Efter de nye regler blev evangelieperikoperne i de to tekstrækker sidestillet. Den afgørende ændring var, at det nye evangelium skulle messes fra alteret i de år, hvor der blev prædiket over det gamle evangelium.

Reglerne betød, at der ved fuld messe var to evangelielæsninger, på linje med reglerne i Kirkeritualet 1685. Men til forskel fra Kirkeritualet var det nu to forskellige evangelielæsninger. Evangeliet fra den gamle række blev stadigvæk læst eller messet ved alle højmesser, men det ene år blev det læst fra prædikestolen i tilknytning til prædikenen, og det andet år blev det messet fra alteret. Denne ordning var gældende frem til alterbogen af 1992 og er i princippet fortsat en mulighed.

Bekendtgørelsen blev på lavere juridisk niveau samme dag fulgt op af et cirkulære. Ændringerne havde været til forhandling på landemoderne i sommeren 1896, og her havde man anbefalet, at man fremover holdt fuld messe. Ministeriet tilslutter sig denne anbefaling og anmoder biskopperne

... om at ville henlede paagældende Præsters Opmærksomhed på det $ø$ nskelige i, at de samtidigt med at indføre de nu bifaldte Ændringer i Gudstjenesten genindføre den i Kirkeritualet ogsaa paa de almindelige Søndage forudsatte fulde Messe, hvor denne maatte være gaaet af Brug, ${ }^{38}$

Selv om man i ministeriet formentlig betragtede den halve messe som værende i modstrid med Kirkeritualet, nøjedes man med en henstilling. Og allerede få måneder senere, den 10. april 1897, var ministeriet nødt til at udsende et supplerende cirkulære, hvor man godt nok opretholdt det ønskelige $i$ at genindføre den fulde messe, men samtidigt kom med anvisninger for, hvordan præsterne skulle holde gudstjeneste, hvis det alligevel var nødvendigt at undlade afholde af fuld messe. I dette tilfælde skulle præsten forholde sig på den måde

... at den gamle Episteltekst messes (oplæses) fra Alteret i de Kirkeaar, da der prædikes over de gamle Evangelier, medens den nye Episteltekst skal messes, naar der prædikes over de nye Evangelietekster. ${ }^{39}$

37. Bekendtgørelse angaaende nogle Forandringer i den almindelige Gudstjeneste paa Søn- og Helligdage. Aftrykt i: Love og Ekspeditioner vedkommende Kirke- og Skolevasen 1897-98, 21-22.

38. Cirkulære til Biskopperne ang. Indførelsen af de ved kgl. Resolution af 22. Januar 1897 bifaldte Forandringer i Gudstjenesten samt Indførelse af fuld Messe på de almindelige Søndage. Aftrykt i: Love og Ekspeditioner 1897-98, 22-23.

39. Cirkulære (til Biskopperne) ang. Brugen af Evangelierne ved Altertjenesten, naar fuld Messe ikke holdes. Aftrykt i: Love og Ekspeditioner 1897-98, 63. 
Traditionen med at holde halv messe og kun messe epistlen fra alteret var formentlig så udbredt, at den ikke lige med det samme kunne bringes til ophør med en uforpligtende henstilling i et cirkulære.

Det lader til, at den halve messe gik ud af brug i løbet af første halvdel af 1900-tallet, og at der i en almindelig højmesse blev messet eller læst to bibeltekster fra alteret, først en epistel og dernæst et evangelium. Endnu i 1922 forudsætter Ernst Hansen dog i sin Messebog, at der er mulighed for at holde halv messe. ${ }^{40}$

I 1936 skrev N.A. Larsen en bog, hvor han forholder sig kritisk til gudstjenestens mangel på fast orden: Folkekirkens Gudstjeneste og de kirkelige Handlinger. ${ }^{41}$ Bogen var foranlediget af arbejdet i udvalget om forholdet mellem stat og kirke. Udvalget arbejdede i perioden 1928-1940, og N.A. Larsen var medlem af udvalget. Han anfører her forskellige eksempler på gudstjenstlig uorden, hvor præster ikke følger de gældende liturgiske bestemmelser i folkekirken. Men han nævner ikke eksempler på, at præster undlader evangelielæsningen fra alteret. Så man kan måske gå ud fra, at denne praksis ikke længere var almindelig udbredt i 1930'erne.

\section{Indforelse af den apostolske trosbekendelse}

I forbindelse med indførelsen af anden tekstrække i slutningen af 1800-tallet blev der revideret på forskellige andre detaljer i højmesseordningen, men der blev ikke i samme forbindelse fastsat nye regler for trosbekendelsens anvendelse og placering.

I princippet var Kirkeritualets bestemmelse om brugen af trossalmen efter evangelielæsningen fra alteret ikke ophævet. Der var med reskriptet i 1802 kommet en radikal omfortolkning af reglerne, sådan at trossalmen kun skulle synges hver anden gang i højmessens begyndelse forud for kollekten og epistlen. Men selv hvis man brugte dette reskript, blev trossalmen ofte indplaceret et andet sted i højmessen end det skulle ifølge reskriptet. Ifølge Cederfeld de Simonsens lille håndbog i 1885 blev trossalmen eller jubelsalmen sunget mellem epistlen og evangeliet (Cederfeld 1885, 6-7 \& 36-38). Viggo Sannes messehåndbog fra 1879 omtaler slet ikke trossalmen, men taler i stedet om to indgangssalmer, den første efter indgangsbønnen og den anden efter epistlen (Sanne 1879, 1 \& 5).

Selv om reskriptet fra 1802 strengt taget kun vedrørte brugen af Balles salmebog, sørgede man dog for, at præster, der ønskede at følge anvisningerne i reskriptet og anvende senere salmebøger, kunne

40. Ernst Hansen. Messebog. København: Tutein \& Koch 1922, 10.

41. N.A. Larsen. Folkekirkens Gudstjeneste og de kirkelige Handlinger. København: Gyldendalske Boghandel 1936. 
anvende de salmenumre, der blev henvist til i reskriptet. Trossalmen havde også nr. 1 både i Psalmebog til Kirke- og Huus-Andagt fra 1855 (Roskilde Konvents Salmebog) og Psalme-Bog for Kirke og Hjem fra 1899. Men det så ikke ud til, at mange brugte muligheden for at synge trossalmen i slutningen af 1800-tallet eller første halvdel af 1900-tallet.

I stedet kom der fra forskelligt hold forslag om bruge den apostolske trosbekendelse efter evangelielæsningen fra alteret. Denne placering af en trosbekendelse var i overensstemmelse med Kirkeordinansen og Kirkeritualet, men havde ikke i praksis været en mulighed i den periode, hvor den halve messe havde været meget udbredt, og hvor der slet ikke var nogen evangelielæsning fra alteret.

Efter min vurdering hænger forslaget om igen at have en trosbekendelse fra alteret efter evangelielæsningen blandt andet sammen med genindførelsen af den fulde messe i forbindelse med indførelsen af anden tekstrække. Der er dog formentlig også andre faktorer, der gør sig gældende, men forslagene kom især frem efter 1885 - og det tyder på en sammenhæng.

Forslaget om at bruge den apostolske trosbekendelse i højmessen efter evangeliet blev fremsat i 1886 af Det kirkelige Råd som en del af et forslag til andre ændringer af højmessens første del før prædikenen. Men det blev ikke til noget. ${ }^{42}$ Forslaget blev også fremsat af forskellige enkeltpersoner før århundredskiftet, blandt andet provst Cederfeld de Simonsen i 1887 og Georg V. Hansen i 1890 og 1895 (Barfoed 1899, 93-110). Men det var først i midten af 1900-tallet, at der kom en afklaring på officielt niveau.

Det var ikke i forlængelse af den hidtidige danske liturgitradition at foreslå, at trosbekendelsen i gudstjenesten skulle være den apostolske trosbekendelse. Men det var lang tid siden, at den nikænske trosbekendelse havde været i brug, og den havde desuden aldrig været $\mathrm{i}$ brug i dansk oversættelse. ${ }^{43} \mathrm{Og}$ trossalmen var tilsyneladende gået så meget ud af brug, at der ikke var nogen, der forsøgte at argumentere for, at den burde genindføres i overensstemmelse med Kirkeritualet. I stedet lod der til i perioden at være almindelig tilslutning til forslaget om at bruge den apostolske trosbekendelse i prosaform.

Den apostolske trosbekendelse var kendt fra dåbsritualet og fra katekismen. Den blev brugt i andre kirker, fx den svenske liturgiske håndbog fra 1811 og 1894 (Martling 1992, 207-213). I dansk sammenhæng blev den apostolske trosbekendelse fremhævet markant af Grundtvig, som samtidig var meget forbeholden over for den nikæn-

42. Se Chr. Barfoed. Vor Høimesse. Kiøbenhavn: Lehmann \& Stage 1899, 95-99.

43. Jf. Holger Villadsen. "Nikænum i dansk liturgisk tradition". Dansk Teologisk Tidsskrift 71 (2008): 1-27. 
ske trosbekendelse. Det antages almindeligvis, at det var grundtvigske kredse, der indførte brugen af den apostolske trosbekendelse i den danske højmesse.

K.E. Skydsgaard skriver i sin kortfattede liturgihistorie, at det var grundtvigske præster, der igen fik trosbekendelsen med ind i gudstjenesten, men "nu paa Prædikestolen, først og fremmest som Daabsbekendelse". ${ }^{44}$ Traditionen hos grundtvigske præster kan forklare valget af den apostolske trosbekendelse, men det kan ikke forklare trosbekendelsens liturgiske placering fra alteret efter evangelielæsningen. Den omtalte grundtvigske praksis hører formentlig hjemme i sidste halvdel af 1800-tallet, hvor det var almindeligt med halv messe uden evangelielæsning fra alteret, og hvor der ikke var en oplagt mulighed for at placere trosbekendelsen fra alteret.

Selv om ønsket om at bruge den apostolske trosbekendelse i gudstjenesten ikke blev understøttet af ministerielle bekendtgørelser og kongelige resolutioner, var det i 1930'erne blevet praksis mange steder. N.A. Larsen, der i sin bog om Folkekirkens Gudstjeneste fra 1936 er optaget af at fremhæve gudstjenestens mangel på fast orden, gør opmærksom på, at trosbekendelsen bliver brugt i forskellige former. Forsagelsen medtages eller medtages ikke, præsten vender sig mod alteret eller mod menigheden, og der bruges forskellige tekstformer (Larsen 1936, 31-32). Selv om N.A. Larsen kritiserer, at man bruger trosbekendelsen ved altertjenesten, uden at det har hjemmel i kirkelig lovgivning, er han samtidigt en bevidnelse af, at den nye skik i 1930 'erne var blevet udbredt flere steder. Biskopperne valgte samme år at udsende et brev, hvor de godkendte, at den apostolske trosbekendelse kunne bruges ved højmessen efter evangeliet (Skydsgaard 1943, 58).

En anden kilde fra 1930'erne er Harald Kents bog fra 1937 om Brandpunkter $i$ Reformationstidens Gudstjenesteordning. 45 Hovedsagen i bogen er en nyudgivelse af Frans Vormordsens messehåndbog fra 1539, men der er også bemærkninger om liturgisk praksis i samtiden. Luthers trossalme "bruges meget sjældent i det hele taget, mens Menigheden i vore Dage dog er i Færd med at generobre Søndags-Højmessepladsen for Trosbekendelsen selv, men rigtignok ikke den 'nikænske', som Meningen var" (Kent 1937, 34).

K.E. Skydsgaard går i 1943 ud fra, at den apostolske trosbekendelse nu er en del af højmessen, og at den siges af præsten efter evangeli-

44. Skydsgaard 1943, 58. Tilsvarende bemærkninger findes forordet til Dansk Kirkesangs forslag til en dansk højmesseliturgi i Dansk Kirkesangs Aarsskrift 1943, 5.

45. Harald Kent. Brendpunkter i Reformationstidens Gudstjenesteordning med en $N y$-udgivelse af 1539-Haandbogens Gudstjenestedel og Nodebilag samt Ordinansens Anvisning og Nodebilag. København: Levin \& Munksgaard 1937. 
elæsningen, vendt mod alteret. Og han skriver, at trosbekendelsen har "vundet Indpas i snart de fleste Menigheder og har mange Steder faaet sin gamle Plads efter Evangeliet foran Alteret, hvilket ogsaa er blevet godkendt ved Biskoppernes Rundskrivelse til Præsterne i 1936" (Skydsgaard 1943, 58).

\section{Biskppernes Vejledning med højmesseordning}

Det kirkelige udvalg af 1928 om forholdet mellem staten og folkekirken gør i sin betænkning fra 1940 opmærksom på, at der i folkekirken mangler en samlet fremstilling af, hvordan gudstjenesten skal udføres. ${ }^{46}$ Gudstjenesten er derfor i stigende omfang kommet til at lide af usikkerhed og uensartethed (Betænkning 1940, 119-120). Et stort flertal i udvalget vedtager derfor en henstilling: "Udvalget henstiller til Kirkeministeriet at udgive en Haandbog med de nugældende Regler for Udførelsen af Gudstjenesten og de kirkelige Handlinger i Folkekirken” (Betænkning 1940, 121).

Resultatet af denne henstilling blev, at de danske biskopper i 1949 udsendte en Vejledning $i$ den danske folkekirkes gudstjenesteordning med de autoriserede ritualer (Biskoppernes Vejledning). ${ }^{47}$ De omtaler selv $\mathrm{i}$ forordet, at håndbogen er blevet udarbejdet på baggrund af et forslag i det kirkelige udvalg af 1928, og fremsætter et ønske om, "at denne vejledning må virke til gavn for en sund forening af fasthed og frihed i den kirkelige tjeneste" (Biskoppernes Vejledning 1949, 5).

Biskoppernes Vejledning indeholdt en højmesseordning, og det var første gang efter reformationen, at den danske kirke fik en egentlig højmesseordning, som var beregnet til brug i kirken og beskrev højmessens forløb samt indeholdt alle de relevante faste tekster.

Men højmesseordningen som sådan var kun en vejledning. Den havde ikke selvstændig lovkraft og var kun en sammenskrivning af eksisterende regler, som i tidens løb var kommet til at afvige på flere punkter fra Kirkeritualet fra 1685. Derudover indeholdt den forskellige praktiske anvisninger, som kun var vejledninger eller anbefalinger.

Salmevalget var nu frit. Der var ikke længere klare spor af anvisningerne i Kirkeritualet 1685 eller i salmereskriptet fra 1802. Salmerne var angivet ved forskellige navne efter deres placering og funktion i

46. Betenkning afgivet af det i Henhold til Lov af 7. Marts 1928 nedsatte Udvalg angaaende Forholdet mellem Staten og Folkekirken. København: Schultz 1940.

47. Vejledning i Den danske folkekirkes gudstjenesteordning med de autoriserede ritualer. Udarbejdet af biskopperne. København: Haase \& Søns Forlag 1949. [Forkortet: Biskoppernes Vejledning 1949]. 
højmesseordningen: indgangssalme, anden salme, salme før prædiken, salme efter prædiken, udgangssalme.

Som anden bibellæsning fra alteret var der en evangelielæsning, indledt med dialog mellem præst og menighed, som svarer: "Gud være lovet for sit glædelige budskab”. Forud for evangelielæsningen fra alteret var der epistellæsning og anden salme; og bagefter var der den apostolske trosbekendelse og salme før prædiken (Biskoppernes Vejledning 1949, 8-10).

At der er en evangelielæsning fra alteret er i overensstemmelse med Kirkeritualet 1685 og Kirkeordinansen 1539. Biskoppernes Vejledning omtaler ikke muligheden af en halv messe med kun en epistelæsning fra alteret, så man må gå ud fra, at denne praksis var ophørt på dette tidspunkt, eller i hvert fald ikke blev betragtet som en ønskelig mulighed.

I overensstemmelse med bekendtgørelsen om anden tekstrække fra 1897 anfører vejledningen i 1949, at det evangelium, der messes eller læses fra alteret, er "dagens evangelium fra den tekstrække, hvorover der ikke prædikes" (s. 9).

Set i et længere historisk perspektiv er evangelielæsningen fra alteret ikke indført for at sikre en evangelielæsning fra den modsatte tekstrække, men er den oprindelige plads for evangelielæsningen. Men opmærksomheden i gudstjenesten som helhed hviler i ordningen med to tekstrækker i højere grad på oplæsningen fra prædikestolen af dagens prædikeevangelium end på evangelielæsningen fra alteret.

Evangelielæsningen fra alteret efterfølges ifølge Biskoppernes Vejledning 1949 af trosbekendelse. Sådan var det også i de første århundreder efter reformationen, men trosbekendelsen havde i 1800-tallet mistet sin gamle plads. Med Biskoppernes Vejledning i 1949 placeres trosbekendelsen igen efter evangelielæsningen fra alteret. Ordningen havde været på vej, siden det blev foreslået i slutningen af 1800-tallet, men det er først med Biskoppernes Vejledning, at trosbekendelsen på mere officielt plan igen placeres på denne plads efter evangelielæsningen.

Der er dog ikke tale om noget påbud. Vejledningen nøjes med at anføre: "Hvor forsagelsen og trosbekendelsen bruges, kan de fremsiges (eller synges) af præsten eller (og) menigheden" (s. 9). Trosbekendelsen kan også fremsiges fra prædikestolen før eller efter evangeliets oplæsning, så placeringen ligger ikke helt fast. Men som den primære placering anføres placeringen efter evangelielæsningen. Vejledningen går klart ud fra, at den trosbekendelse, der anvendes, er den apostolske trosbekendelse, og at den indledes med forsagelsen.

I 1953 kom der en ny salmebog, Den danske Salmebog, som blev autoriseret ved $\mathrm{kgl}$. resolution af 25 . februar 1953. Salmebogen fik 
også en tekst- og bønnebog, som blev indledt med en let forkortet og revideret version af højmesseordningen fra Biskoppernes Vejledning 1949. Ifølge salmebogen er tekst- og bønnebogen autoriseret i forbindelse med selve salmebogen, og dermed skulle højmesseordningen også være autoriseret som et helt nyt træk i dansk liturgihistorie. Den præcise karakter og omfang af denne autorisation forekommer mig dog at være uklar. ${ }^{48} \mathrm{Og}$ der foreligger mig bekendt ikke forarbejder, der lægger op til en sådan nyskabelse, udover Biskoppernes Vejledning fra 1949, som netop kun er en vejledning og en sammenskrivning af foreliggende regler. I forordet til 2. udgave fra 1955 af Biskoppernes Vejledning anfører biskopperne, at

... man har bragt de tekster og bønner, der tillige er optaget i Den Danske Salmebogs Tekst- og Bønnebog i overensstemmelse med den deri foreliggende form, der under 25.2.1953 har modtaget kongelig autorisation. ${ }^{49}$

Her tales der om ændrede tekstformer, der er autoriseret, men ikke entydigt om autorisation af højmesseordningen som helhed. Og højmesseordningen forsynes i Biskoppernes Vejledning fra 1955 heller ikke med en angivelse af, at den er autoriseret ved kgl. resolution af en bestemt dato, ligesom det er tilfældet med eksempelvis dåbsritualerne og nadverritualerne.

I August Roesens kirkeret fra 1960 er der nogle principielle bemærkninger om grundlaget for gudstjenestens ordning, hvor der henvises til Danske Lov og Kirkeritualet. ${ }^{50}$ I den sammenhæng omtales Biskoppernes Vejledning fra 1949 og andenudgaven af 1955, men der er ikke nogen omtale af en autorisation af højmesseordningen i salmebogen 1953. Den manglende omtale tyder på, at Roesen ikke ud fra en juridisk synsvinkel betragter højmesseordningen i salmebogen 1953 som et vigtigt punkt i det juridiske grundlag for dansk gudstjenesteordning.

Men uanset den formelle status af højmesseordningen i salmebogen 1953 har højmesseordningen i salmebogen haft betydning derved, at alle her haft god mulighed for at sætte sig ind i ordningen, idet høj-

48. Jf. Anders Malling. Dansk Salmehistorie. Bind VIII: Salmebøgerne. København: Schultz Forlag 1978, 547. Det fremgår af Mallings bemærkninger, at salmebogens prosadel er blevet til under biskop Høgsbros ledelse, og at prosadelen ikke havde været en del af salmebogskommissionens arbejde.

49. Vejledning i Den danske folkekirkes gudstjenesteordning med de autoriserede ritualer. Udarbejdet af biskopperne, 2. udgave. København: Vajsenhuset 1955, 7.

50. August Roesen. "Nogle afsnit af dansk kirkeret". I Teologisk Stat, udg. af Den danske Præsteforening, red. Jon Iuul. 1960. Hillerød: Rud Pallesen, 7-8. 
messeordningen blev trykt i de fleste salmebøger i perioden fra 1953 til 1992.

\section{Biskoppernes liturgiske udvalg 1953-1963}

Højmesseordningen i Biskoppernes Vejledning 1949 var ikke tænkt som en ændring af højmesseordningen, men kun som en registrering af de relevante aktive liturgiske bekendtgørelser og aktuel praksis. Det var dog ikke planen, at liturgiarbejdet skulle standse med denne registrering, så allerede i 1953 nedsatte biskopperne et udvalg, som fik til opgave at foretage en kritisk revision af ritualer og gudstjenesteordning og komme med forslag til ændringer og suppleringer.

De indledte arbejdet med at udarbejde andenudgaven af Biskoppernes Vejledning i 1955. Derefter udsendte udvalget i 1958 et Forslag til Alterbog (Prøvealterbog). ${ }^{51}$ Udvalget afsluttede sit arbejde i 1963 med et Forslag til Ritualbog (Prøveritualbog). ${ }^{52}$ Forslagene blev ikke autoriserede og fik kun en begrænset virkningshistorie, men det er dog relevant i denne sammenhæng med nogle bemærkninger til evangelielæsningen og trosbekendelsens placering i udvalgets forslag.

Det forudsættes klart i både Prøvealterbog og Prøveritualbog, at der er to evangelielæsninger i højmessen. Der er på dette punkt ikke ændringer i forhold til Biskoppernes Vejledning 1949. Efter anden salme messes eller læses et evangelium fra alteret, og det efterfølges af trosbekendelsen, som primært er den apostolske trosbekendelse, men undtagelsesvist kan være den nikænokonstantinopolitanske bekendelse. Efter salmen før prædikenen indleder præsten på prædikestolen med at læse dagens evangelium (Prøveritualbog 1963, 23-26).

Prøvealterbogen foreslår, at der skal være tre tekstrækker, blandt andet fordi de øvrige nordiske kirker har tre tekstrækker og ikke tænker på at gå bort fra dem. Samtidigt er det udvalgets opfattelse, "at den ældre række er værdifuldere end anden række og den nye tredje række" (Prøvealterbog 1958, 9). Derfor foreslår udvalget, at der prædikes over første tekstrække hver andet år, og hver andet år skiftevis over anden og tredje. Der bliver altså en fireårig turnus: 1. række - 2 . række - 1. række-3. række.

Samtidigt ønsker man at sikre, at den gamle evangelierække altid kommer til at lyde ved fuld højmesse. Det sker ved, at det gamle evangelium læses som prædiketekst hvert andet år. Og de år, hvor

51. Forslag til Alterbog for Den danske evangelisk-lutherske Folkekirke. Kollekter, lektier, epistler og evangelier samt Jesu Kristi lidelses historie. København: Vajsenhuset 1958.

52. Forslag til Ritualbog for Den danske evangelisk-lutherske Folkekirke. Gudstjenester og kirkelige handlinger. København: Vajsenhuset 1963. 
prædikes over andet eller tredje tekstrække, læses det gamle evangelium fra alteret (Prøvealterbog 1958, 9).

Prøvealterbogen blev ikke autoriseret, men satte sig dog nogle spor, blandt andet ved at foreslå flere gammeltestamentlige læsninger og ved at foreslå to alternative indledningskollekter.

\section{Kun én evangelielæsning i liturgikommissionens forslag (1970-1987)}

Da det stod klart, at Prøvealterbogen 1958 og Prøveritualbogen 1963 ikke ville blive autoriseret, blev det hurtigt besluttet at gøre et nyt forsøg på at få lavet en revision af folkekirkens alterbog og ritualer, herunder også højmesseordningen. Kirkeministeriet nedsatte i 1970 en liturgisk kommission, der arbejdede frem til 1987 og fremlagde forskellige betænkninger. Relevant i denne sammenhæng er især betænkning nr. 625 fra 1971 om En foreløbig revision af højmessen, ${ }^{53}$ betænkning nr. 750 fra 1975 om De bibelske lasninger i gudstjenesten, ${ }^{54}$ og betænkning nr. 1057 fra 1985 med Forslag til Alterbog..$^{5}$

Karakteristisk for liturgikommissionens forslag var, at der kun var én evangelielæsning. På dette punkt afveg den fra de tidligere danske højmesseordninger, hvor der havde været to evangelielæsninger, den første fra alteret og den anden fra prædikestolen.

Og når der kun er én evangelielæsning, skal der træffes et valg vedrørende placeringen. Liturgikommissionen foretrak tilsyneladende placeringen fra alteret, men havde også en alternativ mulighed, hvor evangelielæsningen foregik fra prædikestolen.

Liturgikommissionen blev på sit første møde enige om, at man i den foreløbige revision blandt andet ville tilstræbe at udarbejde et forslag til "indskrænkning af antallet af bibelske læsninger i højmessen" (Betænkning 1971, 5). Og man nåede frem til et forslag om, at det evangelium, som der ikke prædikes over, kan udelades:

53. Kirkeministeriets liturgiske kommission. Betenkning om en foreløbig revision af højmessen (herunder dåb og nadver). Betænkning nr. 625. København 1971. [Forkortet: Betænkning 1971].

54. De bibelske lasninger $i$ gudstjenesten. Betænkning afgivet af Kirkeministeriets liturgiske kommission. Betænkning nr. 750. København 1975. [Forkortet: Betænkning 1975].

55. Forslag til Alterbog. Betænkning afgivet af Kirkeministeriets liturgiske kommission. Betænkning nr. 1057. København 1985. [Forkortet: Betænkning 1985]. 
De bibelske læsninger kan indskrænkes til to, nemlig de to læsninger fra den tekstrække, hvis evangelium der prædikes over i det pågældende kirkeår, således at epistelen eller lektien læses på sin sædvanlige plads efter kollekten og før 2. salme.

Evangeliet læses enten fra alteret efter 2. salme og før salmen før prædikenen, således at præsten på prædikestolen straks begynder på sin prædiken (evt. kan prædikenen indledes med en kort genfortælling af evangeliet), eller præsten går på prædikestolen efter 2. salme, læser evangeliet og begynder på sin prædiken (Betænkning 1971, 23).

Der er ikke nogen nærmere begrundelse for forslaget udover, at det vil give mulighed for at forkorte højmessen. Liturgikommissionen gør heller ikke noget forsøg på at perspektivere forslaget i forhold til dansk liturgihistorie.

Den foreslåede ordning minder på flere punkter om den udbredte halve messe i 1800-tallet, men afviger fra denne ordning ved at foreslå to placeringsmuligheder for evangelielæsningen: enten fra alteret eller fra prædikestolen.

På grundlag af liturgikommissionens første betænkning i 1971 blev der i 1972 autoriseret nogle Foreløbige Andringer i Ritual-og Alterbog, der blev trykt som bog i $1973 .{ }^{56}$ Bogen indledes med en højmesseordning, hvori alle ændringer er indarbejdet i en gennemgang af hele højmessen (Foreløbige Ændringer 1973, 7-32). Det ser ud til, at udgangspunktet har været højmesseordningen i salmebogen 1953. Det fremgår ikke klart, hvem der har foretaget denne indarbejdelse af ændringerne, men det er formentlig Kirkeministeriet.

I Foreløbige Andringer har evangelielæsningen fra alteret klar førsteprioritet. Den får en selvstændig overskrift anbragt imellem anden salme og trosbekendelsen, og der er ikke under punktet omtalt andre muligheder for placering af evangelielæsningen (8).

Trosbekendelsen har også et selvstændigt punkt, anbragt mellem evangelielæsning og salmen før prædikenen, mens præsten er for alteret. Her omtales det, at forsagelsen og trosbekendelsen også kan fremsiges fra prædikestolen før eller efter evangeliets oplæsning (8-9).

Under omtalen af prædikenen forudsættes som udgangspunkt, at evangeliet er læst fra alteret, og at præsten straks begynder på sin prædiken. Først derefter omtales det, at præsten også kan gå på prædikestolen efter 2. salme og oplæse evangeliet som sædvanligt. Denne mulighed fremtræder i Foreløbige Andringer som en undtagelse, og

56. Foreløbige Andringer i Ritual-og Alterbog. Autoriseret ved kgl. resolution af 20. november 1972. Udgivet ved Kirkeministeriets foranstaltning. København: P. Haase \& Søn 1973. Autorisationen ophævet igen i 1992. 
en evangelielæsning i forbindelse med prædikenen får ikke en selvstændig overskrift (10).

Højmesseordningen i Foreløbige Endringer får også betydning for den endelige betænkning i 1985, Forslag til Alterbog, for det er den samme skabelon og den samme tekst, der er udgangspunktet for betænkningens forslag til højmesseordning.

I 1975 udsendte liturgikommissionen endnu en foreløbig delbetænkning om De bibelske lasninger $i$ gudstjenesten. Et hovedpunkt var her, at der blev foreslået en indgangslæsning fra Det Gamle Testamente, samt at den gamle epistel blev brugt som udgangslæsning forud for den aronitiske velsignelse. Hvad angår evangelielæsningens placering i højmesseordningen, var der ikke noget nyt i forhold til Foreløbige Andringer. Der var i alterbogen to evangelietekster til hver søn- og helligdag, men der forudsattes kun læst ét evangelium.

Betænkningen indeholder ikke en egentlig højmesseordning, så den måtte præsten selv tilpasse efter omstændighederne, hvis man lokalt ønskede at bruge betænkningen som forsøgsordning. Нøjmesseordningen i Foreløbige Andringer kunne dog bruges, stort set som den var, blot epistlen blev erstattet af den gammeltestamentlige indgangslæsning, og der blev tilføjet en udgangslæsning forud for velsignelsen.

Betænkningen indeholdt et efterskrift med seks punkter, herunder et punkt om læsningernes funktion (197-202). Der argumenteres her for en nyordning, hvor hver af de tre bibelske læsninger har hver sin bestemte plads i det gudstjenstlige forløb og sin egen selvstændige funktion, "der bedre svarer til den kristne gudstjenestes væsen og indhold og til de bibelske skrifters egen hensigt" (199). I den sammenhæng er det et vigtigt punkt, at der kun skal være én evangelielæsning, nemlig det evangelium, hvorover der prædikes.

\footnotetext{
Allerede i Betankning $n r$. 625, side 23, har man peget på, at man kan nøjes med to læsninger i formessen, se også Foreløbige andringer i ritualog alterbog, side 8.3 læsninger vil nemlig ofte være en for stor intellektuel udfordring for menigheden. Læsningen af det ekstra evangelium fra alteret kommer let til at nedbryde koncentrationen om det evangelium, der læses fra prædikestolen. Derfor foreslår man også her, at læsningernes antal i formessen indskrænkes til to, d.v.s. at man kun læser det evangelium, hvorover der prædikes (s. 198-199).
}

I forhold til Betenkning nr. 625 fra 1971 argumenteres der i denne betænkning fra 1975 udførligere for at nøjes med én evangelielæsning, men det spiller stadigvæk en rolle i argumentationen, at det nemt bliver for meget med tre læsninger i formessen. Og til forskel fra 
Prøvealterbogen fra 1958 er det i liturgikommissionen af 1970 ikke længere opfattelsen, at det er et vigtigt punkt at sikre, at evangeliet fra den gamle tekstrække også bliver læst, når der prædikes over evangeliet fra anden tekstrække.

Liturgikommissionens endelige forslag til revision af den danske højmesse kom i 1985 i Betænkning nr. 1057 med Forslag til Alterbog. I forhold til den foreløbige betænkning fra 1975 er der nu en gammeltestamentlig indgangslæsning til begge tekstrækker, mens der uændret er to prædiketekster fra evangelierne.

Forslaget til alterbog indledes nu med et forslag til højmesseordning, som hvad angår evangelielæsning, trosbekendelse og prædiken stort set er uændret i forhold til Foreløbige Andringer. Der er er kun én evangelielæsning, og den messes eller læses som udgangspunkt fra alteret efter anden salme. ${ }^{57}$

Evangelielæsningen efterfølges umiddelbart af trosbekendelsen. I forhold til tidligere er det et nyt træk, at den nikænske trosbekendelse er anført som et alternativ til den apostolske trosbekendelse. Den nikænske trosbekendelse står ikke længere i en fodnote, men i selve teksten efter et "eller". Som udgangspunkt siges (eller synges) trosbekendelsen af præst eller menighed for alteret (6-7).

Under prædikenen er det anført, at evangeliet alternativt kan læses fra prædikestolen efter anden salme. I givet fald kan trosbekendelsen også fremsiges fra prædikestolen, eller den kan anbringes fra alteret som eneste led mellem anden salme og salmen før prædikenen (7).

Evangelielæsningen og trosbekendelsen er i store træk anbragt på samme plads som i Kirkeordinansen 1539 og Kirkeritualet 1685. De er begge som udgangspunkt placeret fra alteret, og evangelielæsningen efterfølges af trosbekendelse. Men så vidt jeg kan se, argumenterer liturgikommissionen ikke nogen steder med, at denne placering og rækkefølge er i overensstemmelse med ældre dansk tradition. Og liturgikommissionen foreslår også alternativer, der ikke kan findes i den ældre danske tradition.

\section{Den Danske Alterbog 1992 med kun én evangelielæsning}

Liturgikommissionens Forslag til Alterbog blev ikke autoriseret i den foreslåede form. Kirkeministeriet anmodede biskopperne om en udtalelse, og de svarende, at de ville udtale sig efter en forsøgsperiode på

57. Betænkning 1985, 6. Jeg citerer fra selve alterbogen. Højmesseordningen findes også i det særskilte indledningsbind, men her er der andre sidetal. 
to år (1986-1988). På baggrund af udtalelserne efter forsøgsperiodens udløb besluttede biskopperne sig for at foreslå en revision. I juni 1991 fremlagde biskopperne et oplæg til høring, hvor der i et forord redegøres nærmere for det reviderede forslag. ${ }^{58}$

Efter yderligere revision indsendte biskopperne i foråret 1992 en indstilling til kirkeministeren, og kirkeministeren anbefalede, at biskoppernes indstilling blev autoriseret. Alterbogen med tilhørende højmesseordning blev autoriseret af Dronningen den 12. juni 1992, og sidst på året blev Den Danske Alterbog trykt med den nye bibeloversættelse fra 1992 indarbejdet. ${ }^{59}$

I mange henseender er liturgikommissionens alterbogsforslag fra 1985 udgangspunktet for den nuværende alterbog, mest markant med den indledende læsning fra Det Gamle Testamente. Men netop i forhold til evangelielæsningens og trosbekendelsens placering i højmesseordningen, som er emnet for denne artikel, er der nogle ikke ubetydelige forskelle.

Evangelielæsningen er i højmesseordningen fra 1992 placeret på prædikestolen i tæt forbindelse med prædikenen. Evangelielæsningen fra prædikestolen har et særskilt punkt i højmesseordningen, efter salmen før prædikenen og forud for selve prædikenen (Ritualbog 1992, 21-22, pkt. 10).

At der er en evangelielæsning fra prædikestolen, er ikke et nyt punkt i dansk liturgihistorie; sådan har det været hele tiden siden reformationen, eller $\mathrm{i}$ hvert fald så langt tilbage, at der fandtes prædikestole i de danske kirkerum. Men det er et nyt punkt i dansk liturgi, at der ikke også er en evangelielæsning fra alteret.

Den autoriserede højmesseordning fra 1992 stemmer overens med liturgikommissionens forslag fra 1985 på det punkt, at der kun er én evangelielæsning, men de afviger fra hinanden ved placeringen. Liturgikommissionen placerer som udgangspunkt evangelielæsningen fra alteret, mens den autoriserede højmesseordning fra 1992 som udgangspunkt har evangelielæsningen fra prædikestolen.

Hverken liturgikommissionen eller biskopperne argumenterer eksplicit for den ene placering af evangelielæsningen frem for den anden,

58. Oplag til Gudstjenesteordning. Udarbejdet af biskopperne juni 1991. Frederiksberg: Materialecentralen 1991, VII-XVI. Jf. Holger Villadsen. "Tilbagemeldinger på Liturgikommissionens Alterbogsforslag. En foreløbig oversigt ved forsøgsperiodens udløb”. Kritisk forum for praktisk teologi 35 (1989): 5-18.

59. Den Danske Alterbog. Autoriseret ved kgl. resolution af 12. juni 1992. København: Vajsenhuset 1992. Højmesseordningen findes Alterbog 1992, 7-38, men er også trykt i Ritualbog. 1992. København: Vajsenhuset, 17-46. Jf. Olav Lindegaard. "Den Danske Alterbogs tilblivelse". Kirkehistoriske Samlinger 2010: 17-46; samt Holger Villadsen. Folkekirkens gudstjenestereform 1992. Liturgiske artikler og foredrag. København: Books on Demand 2011. 
så de forskellige placeringer af evangelielæsningen, må formentlig betragtes som afledte og til dels utilsigtede konsekvenser af andre forskelle, herunder især udgangslæsningen.

Liturgikommissionen havde foreslået, at der skulle være en indledende bibellæsning fra Det Gamle Testamente. Der havde i udtalelserne fra præster og menighedsråd efter forsøgsperioden 1986-1988 været bred tilslutning til dette forslag. Så biskopperne tilsluttede sig dette punkt, selv om det konkrete perikopevalg blev revideret i mindre omfang. ${ }^{60} \mathrm{Og}$ den autoriserede højmesseordning fra 1992 indledes med læsning fra Det Gamle Testamente (pkt. 6).

Liturgikommissionen havde allerede i 1971 foreslået, at der kun skulle være én evangelielæsning i højmessen. Dette punkt blev fastholdt i den endelige betænkning fra 1985. Også dette punkt havde der været almindelig tilslutning til i udtalelserne fra forsøgsperioden 1986-1988. Og biskopperne tilsluttede sig forslaget, som blev et centralt punkt i højmesseordningen fra 1992.

Derimod kunne biskopperne ikke tilslutte sig liturgikommissionens forslag om at bruge den gamle epistellæsning som udgangslæsning forud for velsignelsen. Det havde kommissionen foreslået allerede i betænkning nr. 750 fra 1975, og det blev fastholdt i den endelige betænkning nr. 1057 fra 1985. Men det var et punkt, som der havde været en del kritik af i høringen, og dette punkt blev ikke en del af højmesseordningen i 1992.

I stedet foreslog biskopperne, at epistlen skulle læses som bibellæsning nr. 2 efter den gammeltestamentlige læsning og inden evangelielæsningen. På den måde kom der tre bibelske læsninger inden prædikenen: gammeltestamentlig læsning, epistel og evangelium.

Det er i et længere dansk perspektiv ikke noget nyt, at der i højmessen er tre bibelske læsninger. Det havde der også været tidligere i de officielle ordninger. Men her havde den anden læsning fra alteret altid været en evangelielæsning, enten dagens evangelium, som senere blev repeteret fra prædikestolen, eller det havde efter 1897 været evangeliet fra den tekstrække, som der ikke blev prædiket over.

Perikopestrukturen med tre bibelske læsninger svarede til det, som var blevet indført i mange andre kirker i sidste del af 1900-tallet, herunder de andre lutherske kirker i Norden. I forbindelse med denne nye perikopestruktur og integreringen af nadveren i en almindelig højmesse blev der samtidigt indført en inddeling af højmessen i fire hoveddele: Indledning (I), Ordet (II), Nadver (III) og Afslutning

60. Se Oplæg til Gudstjenesteordning 1991, XIII. Jf. Holger Villadsen. "På gudstjenestens betingelser. Om valget af gammeltestamentlige læsninger i Den Danske Alterbog (1992)". I Bibelen i gudstjenesten, red. Gitte Buch-Hansen \& Frederik Poulsen. 2015. 109-127. Det Teologiske Fakultet, Københavns Universitet. 
(IV). ${ }^{61}$ En lignende inddeling indgik også i højmesseordningerne i de andre nordiske kirker. De bibelske læsninger, herunder evangelielæsningen, samt trosbekendelsen indgår i anden hoveddel: Ordet.

Den forskellige placering af evangelielæsningen i alterbogsforslaget 1985 og den autoriserede alterbog fra 1992 er efter min vurdering ikke et direkte tilstræbt mål, men en indirekte konsekvens af det forskellige antal bibelske læsninger før prædikenen. I biskoppernes $O p$ lag til Gudstjenesteordning fra juni 1991 er der et forord, der redegør for overvejelserne bag den foreslåede højmesseordning og alterbog. Men der er ikke selvstændige bemærkninger om evangelielæsningens placering.

Liturgikommissionen havde helt tilbage til den foreløbige betænkning fra 1971 og de Foreløbige Endringer i 1973 tilstræbt, at der kun skulle være to bibelske læsninger før prædikenen. Biskopperne endte derimod med at foreslå tre bibelske læsninger for at give plads til både en gammeltestamentlig læsning, en epistellæsning og en evangelielæsning. Hvis det forskellige antal bibelske læsninger indplaceres i forhold til de traditionelle salmer før prædikenen (indgangssalmen, anden salme og salmen før prædikenen), bliver resultatet næsten uundgåeligt, at evangelielæsningen placeres forskelligt, og at tre bibelske læsninger medfører, at evangelielæsningen placeres på prædikestolen efter salmen før prædikenen.

Vurderingen af, at den forskellige placering af evangelielæsningen ikke er et direkte tilstræbt mål, understøttes af, at både liturgikommissionens alterbogsforslag og den autoriserede højmesseordning fra 1992 har en undtagelsesbestemmelse med en anden placering af evangelielæsningen. I højmesseordningen fra 1992 er der en note 2 med to bibelske læsninger, som begge er placeret fra alteret, herunder også evangelielæsningen (Ritualbog 1992, 41-42). Ordningen kan bruges som en forkortelsesmulighed ved morgengudstjenester og andre tilsvarende gudstjenester eller ved gudstjenester med dåb, men den kan også bruges ved alle faste gudstjenester, hvis præsten kan få menighedsrådets samtykke til at udelade én af læsningerne (Ritualbog 1992, 37).

Hvis ordningen med to bibelske læsninger bruges ved alle faste gudstjenester, læses evangeliet fra alteret efter salmen mellem læsningerne (anden salme). Derefter følger trosbekendelsen og salmen før prædikenen. På prædikestolen indledes med en kort bøn. Ordningen svarer i alt væsentligt til det tilsvarende afsnit i højmesseordningen i Foreløbige Andringer 1973.

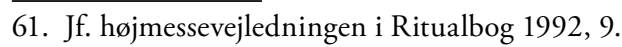




\section{Trosbekendelsens placering i 1992-ordningen}

I højmesseordningen fra 1992 synges eller siges trosbekendelsen som udgangspunkt efter epistellæsningen, mens præsten stadigvæk er for alteret, og forud for evangelielæsningen fra prædikestolen (Ritualbog 1992, 19-21, pkt. 9).

Ud fra en synsvinkel er placeringen uændret i forhold til dansk højmesseordning, sådan som den i hovedtræk har set ud siden Biskoppernes Vejledning 1949. Trosbekendelsen følger efter den anden bibelske læsning og forud for salmen før prædikenen, mens præsten stadigvæk er for alteret.

Ud fra en anden synsvinkel er trosbekendelsens placering blevet ændret. I et længere dansk liturgihistorisk perspektiv har trosbekendelsen været placeret efter evangelielæsningen. Sådan var det i Kirkeordinansen 1539, som på dette punkt fortsatte den middelalderlige tradition. Og sådan var det også i Kirkeritualet 1685, indtil denne ordning gik i opløsning ved salmereskriptet i 1802, som nøjedes med at bruge trossalmen hver anden gang og flyttede den frem i gudstjenestens indledning.

Når højmesseordningen 1992 i normalordningen har placeret trosbekendelsen fra alteret efter anden bibellæsning, epistellæsningen, er der tilstræbt en fortsættelse af dansk liturgisk praksis, samt en tæt sammenhæng mellem evangelielæsningen og prædikenen.

Højmesseordningen 1992 har dog nogle alternativer for trosbekendelsens placering, så ordningen har ikke lagt sig helt fast på en bestemt placering. Når der er tre læsninger, kan trosbekendelsen i stedet fremsiges fra prædikestolen i forbindelse med prædikenen og evangelielæsningen. Og når der kun er to bibelske læsninger, fremsiges trosbekendelsen efter evangelielæsningen, som i den situation bliver den anden læsning fra alteret.

\section{Afslutning}

Dette forsøg på at give et overblik over evangelielæsningens placering i dansk højmesseordning siden reformationen har vist en dobbelthed det meste af tiden, men samtidigt også en forskydning fra alter til prædikestol.

Evangelielæsningens primære placering i de første århundreder, frem til slutningen af 1700-tallet, må siges at være placeringen for alteret, som den anden bibelske læsning. Den var på samme tid liturgisk læsning og prædiketekst. Når evangelielæsningen i denne periode blev gentaget fra prædikestolen, må det betragtes som en praktisk 
og pædagogisk ordning for at sikre, at prædiketeksten blev hørt og forstået. Denne gentagelse af evangelielæsningen blev ikke først indført med Kirkeritualet i 1685, men ser ud til også at have været en del af højmesseordningen i 1500-tallet og 1600-tallet.

I 1700-tallet og 1800-tallet blev evangelielæsningen i stigende omfang betragtet kun som prædiketekst. Forståelsen af evangelielæsningens liturgiske funktion i højmessen som helhed var vigende, og man mente ofte, at evangelielæsningen fra alteret var overflødig, og at det var tilstrækkeligt med evangelielæsningen fra prædikestolen. I en stor del af 1800-tallet var det mest almindelige en halv messe, hvor det fra alteret kun var epistlen, der blev messet. Den officielle ordning holdt dog fast i, at der også skulle være en evangelielæsning fra alteret.

I forbindelse med indførelsen af anden tekstrække i slutningen af 1800-tallet tilstræbte man at genindføre evangelielæsningen fra alteret samtidigt med, at den evangelietekst, der skulle prædikes over, blev læst fra prædikestolen. Hensigten med ordningen var primært at sikre, at dagens evangelium fra den gamle tekstrække blev læst ved alle gudstjenester. Så der opstod indirekte en distinktion mellem den liturgiske evangelielæsning fra alteret og oplæsningen fra prædikestolen af dagens prædiketekst. Oplæsningen af prædiketeksten fra prædikestolen blev opfattet som det vigtigste element, men evangelielæsningen fra alteret blev opretholdt.

Liturgikommissionen af 1970 mente, at det var for meget med to evangelielæsninger, og at det var bedst med kun én evangelielæsning, selv om der var to tekstrækker. Evangeliet blev i liturgikommissionens forslag normalt læst fra alteret og var på samme tid liturgisk læsning og prædiketekst. Denne ordning kom til udtryk i Foreløbige Endringer 1973 og i Forslag til Alterbog 1985. To supplerende vigtige punkter i alterbogsforslaget fra 1985 var indførelsen af en fast gammeltestamentlig indgangslæsning og flytningen af epistellæsningen til gudstjenestens slutning som udgangslæsning.

Den autoriserede højmesseordning fra 1992 følger liturgikommissionens forslag om at kun at have én evangelielæsning samt indføre en fast indgangslæsning fra Det Gamle Testamente. Men 1992-ordningen afviger fra liturgikommissionens forslag ved at opretholde epistlen i højmessens anden hoveddel, Ordet. Der bliver nu igen tre læsninger, som der har været i den danske højmesses første del det meste af tiden. Men evangelielæsningen flyttes i normalordningen væk fra alteret og op på prædikestolen. 


\section{Trosbekendelsens placering}

Trosbekendelsen har det meste af tiden i den danske højmesse været forbundet med evangelielæsningen som opfølgning og sammenfatning.

De første århundreder efter reformationen fulgte trosbekendelsen efter evangelielæsningen fra alteret. Trosbekendelsen havde i dansk liturgi i disse århundreder primært form af en salme, trossalmen.

Men trossalmen blev i stigende grad opfattet som en salme på linje med andre salmer, og i 1800-tallet blev den flyttet væk fra sin gamle plads efter evangelielæsningen og endte med at gå helt ud af brug.

I løbet af 1900-tallet kom trosbekendelsen tilbage i den danske højmesse på sin gamle plads efter evangelielæsningen fra alteret, men nu som prosa i form af den apostolske trosbekendelse. I Biskoppernes Vejledning 1949/1955 var der dog en alternativ placeringsmulighed for trosbekendelsen, nemlig fra prædikestolen før eller efter evangeliets oplæsning.

De Foreløbige Andringer 1973 og liturgikommissionens alterbogsforslag fra 1985 havde som udgangspunkt en tilsvarende placering af trosbekendelsen som Biskoppernes Vejledning 1949/1955, nemlig fra alteret efter evangelielæsningen.

Den autoriserede højmesseordning fra 1992 har derimod i normalordningen en placering af trosbekendelsen, som afviger fra den forudgående danske tradition i 1900-tallet og den ældste danske tradition i de første århundreder efter reformationen. Forbindelsen med evangelielæsningen ophæves, og i stedet anbringes trosbekendelsen efter epistellæsningen fra alteret.

\section{Litteratur}

Alterbog. 1992. Gudstjenesteordning for Den Danske Folkekirke: Den Danske Alterbog. Autoriseret ved kgl. resolution af 12. juni 1992. København: Vajsenhuset.

Anden Rakke. 1885. Pradiketexter til Kirkeaarets Søn- og Helligdage. Kjøbenhavn: Gyldendalske Forlag.

[Bagger, Hans]. 1688. Forordnet Alterbog udi Danmark og Norge. Kiøbenhavn: Joachim Schmedtgen.

Barfoed, Chr. 1899. Vor Høimesse. Kjøbenhavn: Lehmann \& Stage.

Betænkning. 1940. Betankning afgivet af det $i$ Henhold til Lov af 7. Marts 1928 nedsatte Udvalg angaaende Forholdet mellem Staten og Folkekirken. København: Schultz. 
Betænkning. 1971. Kirkeministeriets liturgiske kommission: Betenkning om en foreløbig revision af højmessen. Betænkning nr. 625. København.

Betænkning. 1975. De bibelske lasninger i gudstjenesten. Betænkning afgivet af Kirkeministeriets liturgiske kommission. Betænkning nr. 750 . København.

Betænkning. 1985. Forslag til Alterbog. Betænkning afgivet af Kirkeministeriets liturgiske kommission. Betænkning nr. 1057. København.

[Biskoppernes Vejledning]. 1949. Vejledning i Den danske folkekirkes gudstjenesteordning med de autoriserede ritualer. Udarbejdet af biskopperne. København: Haase \& Søns Forlag.

[Biskoppernes Vejledning]. 1955. Vejledning i Den danske folkekirkes gudstjenesteordning med de autoriserede ritualer. Udarbejdet af biskopperne, 2. udgave. København: Vajsenhuset.

Borregaard, Svend. 1953. Danmarks og Norges Kirkeritual af 1685. Teologiske Studier II,13. København: Gad.

Brandt, C.J., \& R.Th. Fenger. 1850-1851. Christiern Pedersens Jertegns-Postil, I. Vinterparten, II. Sommerparten. Kjøbenhavn: Gyldendal.

Cederfeld de Simonsen, C.C.S. 1885. Kirkeaaret, Gudstjenesten og de kirkelige Handlinger, en Haandbog for Kirkegjengere og Menighedsmedlemmer. Kjøbenhavn: Th. Lind.

Dansk Kirkesang. 1943. "Forslag til en dansk Højmesseliturgi”, udgivet af Samfundet Dansk Kirkesang. Dansk Kirkesangs Aarsskrift 1943: 1-26.

Engelstoft, C. T. 1840. Liturgiens eller Alterbogens og Kirkeritualets Historie i Danmark. Kjøbenhavn: Reitzels Forlag.

Fogtman, Laurids. 1810. Kongelige Rescripter, Resolutioner og Collegialbreve for Danmark og Norge, udtogsvis udgivne i chronologisk Orden, VI. Deel, 11. Bind, 1801-1802. København: Gyldendal.

Foreløbige Andringer. 1973. Foreløbige Andringer i Ritual-og Alterbog. Autoriseret ved kgl. resolution af 20. november 1972. Udgivet ved Kirkeministeriets foranstaltning. København: P. Haase \& Søn.

Fæhn, Helge. 1994. Gudstjenestelivet i Den norske kirke - fra reformationen til våre dager. Oslo: Universitetsforlaget.

Hansen, Ernst. 1922. Messebog. København: Tutein \& Koch.

Hansen, Georg V. 1895. Oldkirkens Nadveroffer. Dets Forfald og dets Kaar $i$ Nutiden. Kjøbenhavn: Frimodts Forlag.

Jakobsen, Lis. 1918. Peder Palladius, Den aldste danske Alterbog, 1556, udgivet efter originalen. København: Gyldendal. 
Jesperssøn, Niels, 1573. Gradval. En Allmindelig Sangbog ... effter Ordinantzens lydelse. Kjøbenhaffn: Laurentz Benedicht.

Jesperssøn, Niels. 1986. Niels Jesperssøns Graduale 1573. Facsimileudgave ... Udg. af Dansk Organist- og Kantorsamfund og Samfundet Dansk Kirkesang. København: Dan Fog Musikforlag.

Jungmann, Josef Andreas. 1962. Missarum sollemnia. Eine genetische Erklärung der römischen Messe. Fünfte, verbesserte Auflage. Freiburg: Herder.

Kent, Harald. 1937. Brondpunkter i Reformationstidens Gudstjenesteordning med en Ny-udgivelse af 1539-Haandbogens Gudstjenestedel og Nodebilag samt Ordinansens Anvisning og Nodebilag. København: Levin \& Munksgaard.

Kirke-Ritual. 1985. Danmarks Og Norgis Kirke-Ritual, 1685-1985. Genudgivet af Udvalget for Konvent for Kirke og Theologi. Skarrild.

Kornerup, Bjørn. 1934. Hans Tausens Postil. Med Indledning og Noter.

Det danske Sprog- og Litteraturselskab, bind I-II. København: Munksgaard.

Larsen, N. A. 1936. Folkekirkens Gudstjeneste og de kirkelige Handlinger. København: Gyldendalske Boghandel.

Lausten, Martin Schwarz. 1989. Kirkeordinansen 1537/1539. Det danske Udkast til Kirkeordinansen (1537). Ordinatio Ecclesiastica Regnorum Danice et Norwegic et Ducatum Sleswicensis Holtsatice etc. (1537). Den danske Kirkeordinans (1539). Tekstudgave med indledning og noter. København: Akademisk Forlag.

Lindegaard, Olav. 2010. "Den Danske Alterbogs tilblivelse”. Kirkehistoriske Samlinger, 17-46.

Lindhardt, P. G. 1986. Kirke-Ritualet og pietismen. Biskop Peder Herslebs betenkning over Danmarks og Norgis Kirke-Ritual af 1685. København: Akademisk Forlag.

Love og Expeditioner vedkommende Kirke-og Skolevasen 1857/59ff. 1869 ff. Kjøbenhavn: Gyldendal. [Tidsskriftslignende udgivelse over mere end 100 år. Titel i senere årgange ændret til: Love og Ekspeditioner ... ].

Malling, Anders. 1978. Dansk Salmehistorie. Bind VIII: Salmebøgerne. København: Schultz Forlag.

Martling, Carl Henrik. 1992. Svensk liturgihistoria. Stockholm: Verbum.

Matzen, Henning, \& Johannes Timm. 1891. Haandbog i den danske Kirkeret. Kjøbenhavn: Schultz. 
Moth, Matthias. Ca. 1700. "Messe”. I Moths Ordbog. https://mothsordbog. $\mathrm{dk}$ (set 01.12.2020)

[Mynster, Jacob Peter]. 1839. Udkast til en Alterbog og et Kirke-Ritual for Danmark. Kiöbenhavn: Schultz.

Nielsen, Bent Flemming. 2020. Højmessen: Historie og teologi. København: Eksistensen.

Nielsen, Henning. 1985. "Rids af 2. Textrækkes Tilblivelseshistorie". Stiftsbog og landemode-akt for Lolland-Falsters Stift 1985: 23-40.

Oplag til Gudstjenesteordning. 1991. Udarbejdet af biskopperne juni 1991. Frederiksberg: Materialecentralen.

Palladius, Petrus. 1556. Søndagers Oc helige dagers Episteler oc Euangelia met Collecter oc andet at bruge vdi Christi Naduere effter Ordinantzens lydelse. Weydeborgk: Hans Walter. [Moderne udgave: Jakobsen 1918].

Pedersen, Christiern. 1515. Alle Epistler oc Euangelia som lesiss alle Søndage om aared, sammeledis Jule dag, Paaske dagh, Pingetz dag, meth deriss udtydning oc glose oc eth Jertegen til huer dag ... Paris: Josse Badius Ascensius.

Poulsen, S. H. 1959. Danske messebøger fra reformationstiden. Udgivet i facsimile af Universitets-Jubilæets danske Samfund med en liturgihistorisk redegørelse. København: J.H. Schultz.

[Prøvealterbog]. 1958. Forslag til Alterbog for Den danske evangelisk-lutherske Folkekirke. Kollekter, lektier, epistler og evangelier samt Jesu Kristi lidelses historie. København: Vajsenhuset.

[Prøveritualbog]. 1963. Forslag til Ritualbog for Den danske evangelisk-lutherske Folkekirke. Gudstjenester og kirkelige handlinger. København: Vajsenhuset.

Psalmebog. 1798. Evangelisk-kristelig Psalmebog til Brug ved Kirke-og Huus-Andagt. Kiøbenhavn: Vaisenhuses Forlag.

Ritualbog. 1992. Gudstjenesteordning for Den Danske Folkekirke: Ritualbog. København: Vajsenhuset.

Roesen, August. 1960. "Nogle afsnit af dansk kirkeret". Teologisk Stat, udg. af Den danske Præsteforening, red. Jon Iuul, 1-252. Hillerød: Rud Pallesen.

Rørdam, Holger Fr. 1883. Danske Kirkelove ... fra Reformationen indtil Christian V's Danske Lov, 1536-1683, bind I. Kjøbenhavn: Selskabet for Danmarks Kirkehistorie.

Sanne, Viggo. 1879. Messebog. Kjøbenhavn: F. Borchorsts Forlag. 
Skydsgaard, K. E. 1943. "Kirkens Gudstjeneste”. I Haandbog i Kristendomskundskab, bind 6, red. Aage Bentzen m.fl., 7-78. København: Munksgaard.

Sørensen, Søren. 1969. Kirkens Liturgi. 2. rev. udgave. København: Wilhelm Hansens Musikforlag.

Thodberg, Christian. 1965. Den forsømte Gudstjeneste. København: Gad.

Thomissøn, Hans. 1569. Den danske Psalmebog met mange Christelige Psalmer. Kiøbenhaffn: Laurentz Benedicht. [Faksimileudgave udgivet i 1933 af Det danske Sprog- og Litteraturselskab. København: Levin \& Munksgaard].

Ussing, Henrich. 1788. Kirkeforfatningen i de kongelige danske Stater, med dens vigtigste Fordele og Mangler samt muelige Forbedringer, 4. Deel, 1. Bind. Sorøe: J. Lindgrens Enke.

Villadsen, Holger. 1989. "Tilbagemeldinger på Liturgikommissionens Alterbogsforslag. En foreløbig oversigt ved forsøgsperiodens udløb”. Kritisk forum for praktisk teologi 35: 5-18.

Villadsen, Holger. 2008. "Nikænum i dansk liturgisk tradition”. Dansk Teologisk Tidsskrift 71: 1-27.

Villadsen, Holger. 2011. Folkekirkens gudstjenestereform 1992. Liturgiske artikler og foredrag. København: Books on Demand.

Villadsen, Holger. 2015. "På gudstjenestens betingelser. Om valget af gammeltestamentlige læsninger i Den Danske Alterbog (1992)”. I Bibelen i gudstjenesten, red. Gitte Buch-Hansen \& Frederik Poulsen, 109127. Det Teologiske Fakultet, Københavns Universitet.

Vormordsen, Frans. 1539. Een gantske nyttelig oc alle sogneprester oc predicanter nødtørtelig Handbog Om den rette Euangeliske Messe ... Malmø: Oluf Ulriksen. [Faksimileudgave i Poulsen 1959].

Wiberg, Johannes. 1832. Messe-Melodier. Kjøbenhavn: Birck \& Comp. 